\title{
Of Gods and Kings: Natural Philosophy and Politics in the Leibniz-Clarke Disputes
}

\section{Citation}

Shapin, Steven. 1981. Of gods and kings: Natural philosophy and politics in the Leibniz-Clarke disputes. Isis 72(2): 187-215.

\section{Published Version}

http://dx.doi.org/10.1086/352718

\section{Permanent link}

http://nrs.harvard.edu/urn-3:HUL.InstRepos:3353822

\section{Terms of Use}

This article was downloaded from Harvard University's DASH repository, and is made available under the terms and conditions applicable to Other Posted Material, as set forth at http:// nrs.harvard.edu/urn-3:HUL.InstRepos:dash.current.terms-of-use\#LAA

\section{Share Your Story}

The Harvard community has made this article openly available.

Please share how this access benefits you. Submit a story.

Accessibility 


\title{
Of Gods and Kings: Natural Philosophy and Politics in the Leibniz-Clarke Disputes
}

\author{
By Steven Shapin*
}

\begin{abstract}
A
FTER TWO AND A HALF CENTURIES the Newton-Leibniz disputes continue to inflame the passions. Only the very learned (or the very foolhardy) dare to enter upon this great killing-ground of the history of ideas. Recent intense concern with these controversies means that we can no longer reasonably expect the discovery of significant new facts. The emphasis has shifted to interpreting what is already known about these episodes and the setting in which they occurred. This is a highly desirable state of affairs, for the Newton-Leibniz controversies crystallize a number of issues of general significance. What is the proper interpretation of the relations between natural philosophy, mathematics, metaphysics, theology, and the social and political setting in which these matters were disputed?

The elementary anatomy of the controversies is well known. From the late 1690s until about 1714 the stress was upon priority in the discovery of the calculus. Did Leibniz, as Newton and his disciples charged, obtain from Newton the secrets of the calculus in the 1670s? And did Leibniz then obscure this debt while representing his own work as totally independent and original? From about 1710 the disputes began to involve questions in natural philosophy, metaphysics, and religion. These issues reached their greatest prominence during 1715 and 1716, when Leibniz exchanged a series of five letters with the Reverend Samuel Clarke concerning metaphysics, natural religion, God's role in the natural order, the nature of space, matter, and force, and the status of mathematical principles in natural philosophy. Finally, the disputes continued after Leibniz's death in 1716 (and even after Newton's in 1727), developing into a largely experimental and theoretical confrontation between their respective followers over the nature of force in physical inquiries. ${ }^{1}$
\end{abstract}

* Science Studies Unit, University of Edinburgh, Edinburgh, Scotland EH8 9JT.

I gratefully acknowledge the support of the John Simon Guggenheim Memorial Foundation and the hospitality of the Department of History and Sociology of Science at the University of Pennsylvania. For critical comments upon an earlier draft of this paper I wish to thank David Bloor, Lorraine Daston, Margaret Jacob, David Miller, Jeffrey Sturchio, and Christopher Wilde.

'The definitive account of the mathematical priority disputes is now A. Rupert Hall, Philosophers at War: The Quarrel between Newton and Leibniz (Cambridge: Cambridge Univ. Press, 1980); see also the diagrammatic chart in A. Rupert Hall and Laura Tilling, eds., The Correspondence of Isaac Newton, Vol. VI (Cambridge: Cambridge Univ. Press, 1976), p. xxviii. On the 1720s debates concerning vis viva in physics: Carolyn Iltis, "The Leibnizian-Newtonian Debates: Natural Philosophy and Social Psychology," British Journal for the History of Science, 1973, 6:343-377; Iltis, "Leibniz and the Vis Viva Controversy," Isis, 1971, 62:21-35; Thomas Hankins, "Eighteenth Century Attempts to Resolve the Vis Viva Controversy," Isis, 1965, 56:281-297. The classic treatments of the LeibnizClarke exchanges are C. D. Broad, "Leibniz's Last Controversy with the Newtonians," in his Ethics 
The most challenging historiographic problems are posed by the LeibnizClarke exchanges and related episodes, with their explicit conjunction of natural philosophy, metaphysics, and theology. Practically every historian who has addressed these materials has signified in some way where he felt appropriate boundaries should be drawn between different areas of culture. Where the boundaries are placed is reflected in the interpretation each historian offers. Few modern writers follow the old positivist inclination to set interpretive boundaries between "science proper" on the one hand and metaphysics and theology on the other. ${ }^{2}$ Most follow Koyré in demonstrating how metaphysics, theological considerations, and natural philosophy fit into one interacting system of meanings. ${ }^{3}$ Yet even Koyré's contextualism has its limits; no writer in his tradition has seen any point in paying attention to the social and political settings within which the disputes occurred. ${ }^{4}$

A consideration of the political setting is essential to a proper appreciation of the significance of metaphysical, theological, and natural-philosophical disputation in the Leibniz-Clarke controversies. The key notion involved in demonstrating that relevance is the use of philosophical resources in political processes. Different conceptions of God's role in the natural order were used to advance or criticize different notions of the state and the distribution of authority. These conflicting conceptions were sustained by groups with conflicting social interests in the political constitution of late seventeenth- and early eighteenth-century England. ${ }^{5}$ Natural philosophers evaluated conceptions of God and nature in light of their present and past apologetic uses. ${ }^{6}$ Specifically, the English Newtonians'

and the History of Philosophy (London: Routledge \& Kegan Paul, 1952), pp. 168-191; Alexandre Koyré, From the Closed World to the Infinite Universe (Baltimore: Johns Hopkins Univ. Press, 1957), pp. 235-272; F. E. L. Priestley, "The Clarke-Leibniz Controversy," in Robert E. Butts and John W. Davis, eds. The Methodological Heritage of Newton (Toronto: Univ. Toronto Press, 1970), pp. 34-56; Robert Zimmermann, Samuel Clarke's Leben und Lehre (Vienna: Imperial Academy of Sciences, 1870), pp. 52-78; G. H. R. Parkinson, "Science and Metaphysics in the Leibniz-Newton Controversy," Studia Leibnitiana (Supplementa), 1969, 2:79-112.

${ }^{2}$ For an example of such positivism: Margula R. Perl, "Physics and Metaphysics in Newton, Leibniz, and Clarke," Journal of the History of Ideas, 1969, 30:507-526, esp. p. 526; cf. E. W. Strong, "Newton and God," J. Hist. Ideas, 1952, 13:147-167.

${ }^{3}$ Some recent writers have constructed a boundary between the metaphysical and the other aspects of the controversies. To Frank Manuel the metaphysical issues were a "sideshow," the main event being the calculus priority disputes between Leibniz and a man "with an internalized God the Father." Manuel, A Portrait of Isaac Newton (Washington: New Republic Books, 1979; 1st ed., Cambridge, Mass.: Harvard Univ. Press, 1968), p. 333. Rupert Hall's historiographic boundary is explicitly evaluative; the extension of the calculus priority contest to natural philosophical and metaphysical issues was a "regrettable and largely pointless diversification": Hall, Philosophers at War, p. 192.

${ }^{4} \mathrm{~A}$ published account that accords a significant role to political factors (but does not consider intellectual content) is Arnold Thackray, "The Business of Experimental Philosophy': The Early Newtonian Group at the Royal Society," Actes du XIIe Congrès International d'Histoire des Sciences, $1970-1971$, 3B:155-159. Not available while this paper was being written were Larry Stewart, "Samuel Clarke, Newtonianism, and the Factions of Post-Revolutionary England," J. Hist. Ideas, 1981, 42:53-72, and Simon Schaffer, "Newtonian Cosmology and the Steady State" (Ph.D. diss., Univ. Cambridge, 1980). Both offer valuable political perspectives on these episodes, particularly Schaffer, whose account is broadly and gratifyingly similar to mine and contains much greater historical detail.

"The term "England" is used throughout even though after 1707 the relevant polity was "Great Britain.",

${ }^{6}$ For a fuller exposition of this view of the social uses of natural knowledge see Steven Shapin, "Social Uses of Science," in George Rousseau and Roy Porter, eds., The Ferment of Knowledge: Studies in the Historiography of Eighteenth-Century Science (Cambridge: Cambridge Univ. Press, 1980), pp. 93-139. 
reaction to Leibniz's philosophy was shaped by their vested interest in combatting indigenous forms of anti-Newtonian thought which politically opposed groups had used as apologetic resources. Leibniz's philosophy was perceived to share crucially important characteristics with that of the English anti-Newtonian political opposition.

In order to make this interpretation plausible one has to show that Newtonian and anti-Newtonian conceptions were actually used as political tools by social groups. The focus here, therefore, is upon identifying these groups and their interests and not, as is often the case in studies of these disputes, upon diagnosing the motivations or states of mind of individual actors. Whether or not Newton, for example, intended that his philosophy of nature should be put to specific political uses is an interesting question, but it is not our question here, nor need it be. ${ }^{7}$ What do concern us are the historically demonstrable uses to which Newtonian and anti-Newtonian philosophies actually were put, and the social interests served by those uses. In this exercise the historian is in roughly the same position as his historical subjects, for, like them, he has unambiguous access only to visible cultural products and not to the intentions of those who produced them. ${ }^{8}$

\section{THE DYNASTIC CONTEXT OF THE LEIBNIZ-CLARKE EXCHANGES}

As Arnold Thackray has briefly noted, the disputes between Leibniz and the Newtonians were enmeshed with the dynastic politics of England and the house of Hanover. ${ }^{9}$ The location of the two major philosophers in this dynastic setting gives us an entry into assessing the social interests served by conflicting philosophies of nature and God. From the 1670s Leibniz was on the personal staff of Johann Friedrich, duke of Brunswick-Lüneberg, at Hanover, where he acted as librarian, technological advisor, and councilor at court. When the old duke died in 1679 and was succeeded by Ernst August, Leibniz became philosophical tutor to the duchess Sophia. Through his genealogical researches on the house of Brunswick Leibniz was instrumental in securing electoral status for Hanover in the Holy Roman Empire. Leibniz himself became privy councilor and later baron of the Empire. Slighted by Elector Georg Ludwig from 1698, Leibniz busied himself with completing his genealogical work and undertook religious, legal, and political reform at the Hapsburg court in Vienna, where he served from 1712 to

\footnotetext{
${ }^{7}$ Historians are still not agreed about Newton's apologetic intentions. Some have made much of Newton's celebrated letters to Bentley in which he said: "When I wrote my Treatise about our System [the Principia], I had an Eye upon such Principles as might work with considering Men, for the Belief of a Deity, and nothing can rejoice me more than to find it useful for that Purpose." I. Bernard Cohen, ed., Isaac Newton's Papers \& Letters on Natural Philosophy, and Related Documents (2nd ed., Cambridge, Mass.: Harvard Univ. Press, 1978), p. 280. With regard to Newton's possible role in the Leibniz-Clarke letters, one point of view has been that Clarke functioned as Newton's mouthpiece: Alexandre Koyré and I. Bernard Cohen, "Newton \& the Leibniz-Clarke Correspondence," Archives internationales d'histoire des sciences, 1962, 5:63-126, esp. p. 66; see also Koyré, From the Closed World, p. 301; Manuel, Portrait of Isaac Newton, p. 278; Alexandre Koyré and I. Bernard Cohen, "The Case of the Missing Tanquam: Leibniz, Newton \& Clarke," Isis, 1961, 52:555-566, esp. p. 560; A. Rupert Hall and Marie Boas Hall, "Clarke and Newton," Isis, 1961, 52:583-585. Elsewhere Hall has contended that Newton's role was probably minimal: Hall and Tilling, The Correspondence of Newton, Vol. VI, pp. xxix-xxx; Hall, Philosophers at War, pp. 220, $328 \mathrm{n} .23$.

${ }^{8} \mathrm{On}$ some general problems involved in discerning motives and employing this information see Steven Shapin and Barry Barnes, "Darwin and Social Darwinism: Purity and History," in Barnes and Shapin, eds., Natural Order: Historical Studies of Scientific Culture (London/Beverly Hills, Calif.: Sage, 1979), pp. 125-142.

'Thackray, "'The Business of Experimental Philosophy.,"
} 
1714 as imperial privy councilor. In 1714 Georg Ludwig became George I of England. Leibniz bent his efforts towards securing the post of court historian in London, but he failed and was forced to remain in Hanover until he died in 1716.

The English court maintained no salaried philosopher, but in many respects Newton was treated by his contemporaries as its "official" scientific intellectual. Lucasian professor of mathematics at Cambridge from 1669, Newton served as one of the university's two members in the first post-Revolution Parliament and was reelected in 1701. Leaving Cambridge, he was made Warden (later Master) of the Mint by the patronage of the Whig politician Lord Montague. From the accession of Queen Anne until the death of George I Newton was undoubtedly the most influential figure in the official scientific, philosophical, and technological affairs of the nation; there is no question but that he was so perceived by others. He was elected president of the Royal Society in 1703 and knighted by the queen in 1705 . His newly edited and published correspondence reveals just how significant Newton was as an advisor to the crown, in charge of consulting on mining, navigational, and astronomical matters. He was assiduous in securing positions of power and influence for many of his followers and just as diligent in rooting out and pursuing those who crossed him. Moreover, he gave active and substantial advice to a number of Anglican divines whose Boyle lectures from 1692 developed Newtonian natural philosophy into an important apologetic resource for the church and its interests.

Among these Boyle lecturers was Samuel Clarke (1675-1729), a fellow of Gonville and Caius College, Cambridge, from 1696 until 1700. ${ }^{10}$ In 1697 Clarke translated Rohault's Physics into more elegant Latin, adding anti-Cartesian and pro-Newtonian notes to the edition, and in 1706 he performed Newton a greater literary service by translating the Opticks into Latin. In 1698 Clarke succeeded William Whiston as chaplain to Dr. John Moore, bishop of Norwich. After hearing his Boyle lectures in 1704-1705, the queen made Clarke one of her chaplains, and in 1709 he was awarded the rectorship of St. James's, Westminster. It is possible that Clarke was offered, and declined, the position of Master of the Mint upon Newton's death. ${ }^{11}$ Like Newton's his political principles were strongly Whiggish; in theological affairs he was a propagandist for the latitudinarian Low Church faction. His Boyle lectures followed Richard Bentley's in erecting Newtonianism into one of the moral bulwarks of Christianity, while the exchanges with Leibniz defended Newtonian natural religion from perceived threats. ${ }^{12}$ Caroline, princess of Wales, wife of the future George II, presided over and to a large extent initiated the formal interchanges between Clarke and Leibniz. In her youth at the court of Berlin Caroline had been Leibniz's pupil while the philosopher was also instructing Sophia Charlotte, wife to Frederick I of Prussia. In 1705 Caroline married the electoral prince of

\footnotetext{
${ }^{10}$ For biographical information about Clarke see Benjamin Hoadly, "Some Account of the Life, Writings, and Character of [Samuel Clarke]," in John Clarke, ed., The Works of Samuel Clarke, 4 vols. (London, 1738), Vol. I, pp. i-xiv; William Whiston, Historical Memoirs of the Life of Dr. Samuel Clarke (London, 1730); Joel M. Rodney, "Samuel Clarke," in Dictionary of Scientific Biography, Vol. III, pp. 294-297; James Edward Le Rossignol, The Ethical Philosophy of Samuel Clarke (Leipzig: G. Kreysing, 1892).

${ }^{11}$ The Dictionary of National Biography makes this claim, denied by Hall, Philosophers at War, p. 328; Rodney, "Samuel Clarke," recounts a story that Caroline was considering having him made archbishop of Canterbury.

${ }^{12} \mathrm{On}$ the Boyle lectures in general, see Margaret C. Jacob, The Newtonians and the English Revolution 1689-1720 (Ithaca, N.Y.: Cornell Univ. Press, 1976), Chs. V-VI.
} 
Hanover and continued her association with Leibniz. Removing to London with the house of Hanover in 1714, Caroline commenced her contacts with Clarke during her efforts to find a suitable translator of Leibniz's 1710 Théodicée. Clarke became a constant visitor at court, attempting to persuade Caroline of the superiority of Newton's philosophy and almost supplanting Leibniz as her philosophical mentor. ${ }^{13}$

The letters passing between Caroline and Leibniz point to his desperation about his increasingly isolated and unsatisfactory position at Hanover, his unease at the Newtonians' growing influence over his royal pupil, and his frustration over his inability to secure an official position at the English court. Conversely, the Newtonian establishment's concerted effort to discredit Leibniz's mathematical originality dates from the time that the Act of Settlement made it certain that the house of Hanover, with Leibniz as its court philosopher, would be the next royal house of England. ${ }^{14}$ The disputes were seen by participants in nationalistic terms. A friend of Leibniz told him that the controversies were being widely regarded not as a "querelle entre $\mathrm{M}^{\mathrm{r}}$ Newton et moy, mais entre l'Allemagne et l'Angleterre. ..." And after the Hanoverian succession took place, John Keill assured Newton that "Mr. Leibnits after this will not have the impudence to show his face in England. if he does I am persuaded that he will find but few freinds." ${ }^{15}$ But Keill was putting on a brave face. Leibniz would indeed have been a formidable foe had he been invited to London by his Hanoverian patrons. For intertwined with the dynastic politics of Hanover and England were domestic English ecclesiastical, political, and ideological conflicts. By considering these domestic disputes we shall see one of the reasons why Leibniz's philosophy was regarded as so threatening and why the English Newtonians were so concerned to crush it.

\section{WILL VERSUS WISDOM IN THE LEIBNIZIAN AND NEWTONIAN PHILOSOPHIES}

In Samuel Clarke's dedication to Princess Caroline of the 1717 publication of his exchanges with Leibniz he states that natural philosophy, "so far as it affects religion, by determining questions concerning liberty and fate, concerning the extent of the powers of matter and motion, and the proofs from phenomena of God's continual government of the world; is of very great importance." 16 In the early eighteenth-century apologetic setting this bordered on the banal, for it was absolutely standard to infer God's capacities from the constitution of nature and to interpret natural phenomena from the known attributes of the Deity. What

\footnotetext{
13 "Introduction," The Leibniz-Clarke Correspondence, ed. H. G. Alexander (Manchester: Manchester Univ. Press, 1956), pp. ix-lvi, on p. xii.

${ }^{14}$ Thackray, "“The Business of Experimental Philosophy,", p. 156; Hall, Philosophers at War, esp. pp. 118-119, 130-132, 159, 164, 177. Hall, unlike Thackray, makes no explicit connection between the disputes and dynastic politics.

${ }^{15}$ Leibniz to the Princess of Wales, 10 May 1715, in John M. Kemble, ed., State Papers and Correspondence Illustrative of the Social and Political State of Europe from the Revolution to the Accession of the House of Hanover (London: John W. Parker, 1857), pp. 528-531, on p. 529; Keill to Newton, 6 Aug. 1714, in Correspondence of Newton, Vol. VI, pp. 170-171. After Leibniz's death Newton disclaimed any nationalistic interest in the disputes: Newton to Johann Bernoulli, c. 1720, in A. Rupert Hall and Laura Tilling, eds., The Correspondence of Isaac Newton, Vol. VII (Cambridge: Cambridge Univ. Press, 1977), pp. 80-81, although elsewhere there is abundant evidence that the national and dynastic dimensions were recognized: see, e.g., Johann Bernoulli to Leibniz, 3 July 1716, in Correspondence of Newton, Vol. VI, pp. 359-362; Newton to Antonio-Schinella Conti, 26 Feb. 1716, in ibid., pp. 285-290, on p. 285.

${ }^{16}$ Leibniz-Clarke Correspondence, p. 6.
} 
writers in this setting shared were the patterns of inference which meaningfully connected God and nature. What they disagreed about (usually violently) was the set of axioms laid down concerning the nature of God and the nature of nature. This should not surprise us, for what was at stake was as much moral philosophy as natural philosophy. Upon God's attributes and his relationship to the natural order depended a set of ethical prescriptions about how one was to conduct oneself on earth. This clash of theological axioms (and its practical consequences) is particularly evident in the Leibniz-Clarke exchanges. There is little novelty in noting that these disputes were given their basic structure by conflicting appreciations of God's attributes and his relations with the natural order. The Newtonian schema stressed God's voluntary capacities, while the Leibnizian cosmology emphasized his intellectual attributes. Nonetheless, this insight has to be briefly illustrated and stressed, for it is the key to recognizing the political uses of natural philosophy. ${ }^{17}$

A division of natural philosophies into voluntarist and intellectualist orientations was not peculiar to the Leibniz-Clarke controversies. The natural philosophers whom Clarke followed had strongly emphasized the supremacy of God's will. Robert Boyle had construed a law of nature to be a "notional rule of acting according to the declared will of a superior"; God continually exerts his providential will in nature. The Cambridge Platonists asserted that "all created being whatsoever owes the continuation and perpetuity of its existence... to the Divine will only." Newton's own philosophy of nature was firmly anchored in voluntarism and limited voluntarism: ${ }^{18}$ his appreciation of God's supreme will was fundamental to his ontology and epistemology. Newton explained how matter could be created ex nihilo and how our minds could be made to attain the idea of matter by reference to the action of God's will upon absolute space. In Newton's theology man was recommended to reverence God not for his eternity and omniscience, which were his necessary attributes, but for the freedom of his will. Newton's God was an active force in the cosmos, continually ordering, sustaining, and disposing. ${ }^{19}$ In the General Scholium to the second edition of the Principia, written during the height of his personal disputes with Leibniz, Newton addressed the theme of God's active government of the natural world with great vigor. There is little point, Newton said, in referring to a God whose attributes do not include volitional dominion over his servants. We are to adore God "as his servants; and a God without dominion, providence, and final causes, is nothing but Fate and Nature." 20

\footnotetext{
${ }^{17}$ See esp. Koyré, From the Closed World, pp. 235-276, on the so-called "intellectualist-voluntarist" dimensions of Clarke vs. Leibniz; see also Iltis, "Leibnizian-Newtonian Debates," pp. 347-348; Priestley, "Clarke-Leibniz Controversy"; and Edwin Arthur Burtt, The Metaphysical Foundations of Modern Science (New York: Harcourt, Brace \& Co., 1927), pp. 280-299.

${ }^{18}$ Robert Boyle, "A Free Inquiry into the Vulgarly Received Notion of Nature," in Thomas Birch, ed., Works of Robert Boyle, 5 vols. (London, 1744), Vol. IV, pp. 358-424, on p. 367; Ralph Cudworth, The True Intellectual System, 2 vols. (1st Amer. ed., Andover, New Hampshire, 18371838), Vol. I, pp. 104-105. See also John William Duff, "Miracles in a World of Atoms? The Centrality of Providence in Walter Charleton's Mechanical Philosophy” (B.A. diss., Harvard Univ., 1979); Francis Oakley, "Christian Theology and the Newtonian Science: The Rise of the Concept of the Laws of Nature," Church History, 1961, 30:433-457; David Kubrin, "Newton and the Cyclical Cosmos: Providence and the Mechanical Philosophy," J. Hist. Ideas, 1967, 28:326-346; J. E. McGuire, "Boyle's Conception of Nature," J. Hist. Ideas, 1972, 33:523-542; Margaret J. Osler, "Descartes and Charleton on Nature and God," J. Hist. Ideas, 1979, 40:445-456.

${ }^{19}$ Martin Tamny, "Newton, Creation, and Perception," Isis, 1979, 70:48-58; Frank E. Manuel, The Religion of Isaac Newton (Oxford: Oxford Univ. Press, 1974), esp. pp. 21-22.

${ }^{20}$ Isaac Newton, Philosophiae naturalis principia mathematica (Cambridge, 1713), pp. 482-483,
} 
The invocation of God's supreme will as an explanatory and apologetic resource remained a commonplace among Newton's Anglican followers during the late seventeenth and early eighteenth centuries. In his 1692 Boyle lectures Richard Bentley dissolved the problem of the connection between soul and body into an exercise of God's will: "I resolve all that into the sole pleasure and fiat of our omnipotent Creator...." Roger Cotes expressed no doubt that "this World, so diversified with that variety of forms and motions we find in it, could arise from nothing but the perfectly free will of God directing and presiding over all." And John Maxwell's Discourse Concerning God used language strikingly similar to that in Newton's General Scholium: "My proposition is, that God is not rightly defined, a Being absolutely Perfect but that he is more rightly defined, a Spiritual Being endued with Absolute Dominion. . . . A perfect Being, without Dominion, would be only an object of contemplation and admiration, not of worship. . . ."21 One of the most vigorous celebrations of God's will was offered by Clarke himself in his 1704-1705 Boyle lectures. Like Newton, Clarke maintained that a God who did not volitionally and actively intercede in the affairs of the world was no God: "If therefore God does not concern himself in the Government of the World, nor has any regard to what is done therein; it will follow that he is not an Omnipresent, All-powerful, Intelligent and Wise Being; and consequently, that he Is not at all." God's necessary attributes were less worthy of man's reverence than God's active exercise of his perfectly free and sovereign will. ${ }^{22}$

In the 1715-1716 exchanges with Leibniz Clarke's emphasis upon God's supreme will was considerably sharpened; nowhere else does the voluntarist cast of Newtonian thought appear quite as clearly. The protagonists' conflicting views of God's role in the natural order were expressed through the standard seventeenth- and early eighteenth-century clock metaphor. According to Leibniz, "Sir Isaac Newton, and his followers, have also a very odd opinion concerning the work of God. According to their doctrine, God Almighty wants to wind up his watch from time to time. . . . He had not, it seems, sufficient foresight to make it a perpetual motion. . . . [The Newtonians] must needs have a very mean notion of the wisdom and power of God." ${ }^{23}$ To this, of course, Clarke had a ready

quoting from Newton, The Mathematical Principles of Natural Philosophy, trans. Andrew Motte (London, 1729), Vol. II, p. 391.

${ }^{21}$ Richard Bentley, Matter and Motion Cannot Think: or, a Confutation of Atheism from the Faculties of the Soul, in Alexander Dyce, ed., Works of Richard Bentley, 3 vols. (London: Francis Macpherson, 1836-1838), Vol. III, pp. 27-50, on p. 47; Roger Cotes, "Preface," to Newton, Mathematical Principles of Natural Philosophy (1729), Vol. I, Sig. A7; John Maxwell, A Discourse Concerning God (London, 1715), pp. 2, 4, 93; quoted in Priestley, "Clarke-Leibniz Controversy," p. 47n. Maxwell was prebendary of Connor in Ireland from 1720; his 1727 translation of Cumberland's De legibus naturae (see n. 40) was subscribed to by Clarke and Newton and contained an essay by Maxwell defending Clarke on the immateriality of the soul.

${ }^{22}$ Samuel Clarke, A Demonstration of the Being and Attributes of God: more particularly in answer to Mr. Hobbs, Spinoza, and their followers; Clarke, A Discourse Concerning the Unchangeable Obligations of Natural Religion; both in John Clarke, ed., The Works of Samuel Clarke, Vol. II, pp. 513-577, 579-733, quoting p. 602 .

${ }^{23}$ Leibniz-Clarke Correspondence, pp. 11-12. On the clock metaphor generally: L. Laudan, "The Clock-Metaphor and Probabilism: The Impact of Descartes on English Methodological Thought, 1650-1665," Annals of Science, 1966, 22:73-104. Note that it is Leibniz who introduced the notion of a clockwork universe; the Newtonians were never comfortable with this conception, preferring, as did the Cambridge Platonists, a world order maintained by immanent divine activity; see P. M. Heimann, "Nature is a Perpetual Worker': Newton's Aether and Eighteenth-Century Natural Philosophy," Ambix, 1973, 20:1-25. Nevertheless, the Newtonians were prepared to defend the less satisfying notion of God as clock repairer. 
riposte. Any schema which stressed God's perfect wisdom ran the risk of seeming to impugn his perfect and sovereign will. It was a risk the Newtonians declined to take. As Clarke said, "the true glory of God's workmanship is that nothing is done without his continual government and inspection." To conceive of God without the ability to intercede in the natural world tends "to exclude providence and God's government in reality out of the world." A God without the ability to intercede was no God at all; God's government was manifest both in his framing of the regular laws of nature and in his intermittent suspension or alteration of those laws, subject to his sovereign will and pleasure. ${ }^{24}$ Against this notion of God the clock mender, Leibniz brought to bear his great principle of sufficient reason. Clarke was happy to accept the principle that nothing is "without a sufficient reason why it is," but he insisted that "this sufficient reason is oft-times no other, than the mere will of God." As for God's wisdom, this consisted "in framing originally the perfect and complete idea of a work, which begun and continues, according to that original perfect idea, by the continual uninterrupted exercise of his power and government." Thus even Leibniz's arguments in favor of God's paramount wisdom were turned into evidence of the supremacy of his will. 25

Preferences for a voluntaristically or intellectualistically conceived God were consequential-quite obviously for other matters in metaphysics and the philosophy of nature, less obviously consequential for the technical components of the Newtonian schema which Clarke celebrated and defended against attack. In Newton's celestial physics the particular "clock" requiring God's volitional interposition and correction was the solar system. Irregularities in planetary motions that, if left to accumulate, would result in the destruction of the solar system's natural order, needed, in Newton's view, the Deity's intercession to set them right. In the Optice of 1706 Newton noted "some inconsiderable Irregularities" in planetary motions "which will be apt to increase, till this System wants a Reformation." ${ }^{26}$ From this astronomical fact one could, if so inclined, construct a proof of the existence of an interventionist God. Samuel Clarke was so inclined; before the publication of the Optice Clarke asked in his Boyle lectures whether God's existence as a volitional actor was not proved by "the preservation of the several Systems, and of the several Planets and Comets in the same System, from falling upon each other; which in infinite past Time (had there been no Intelligent Governor of the Whole,) could not but have been the Effect of the smallest possible Resistence made by the finest Aether, and even by the Rays of Light themselves, to the Motions . . . of Those Bodies?" 27 Pressed by Leibniz ten years later, Clarke amplified what was meant by the Newtonian "reformation," and how the intermittent exercise of God's will, far from denigrating his wisdom, actually glorified it. "Amendment" or "correction," Clarke stipulated, were relative terms, referring to human apprehensions of the events. But in God's mind all "disorder" and apparent alteration of the frame of things were parts of the

\footnotetext{
${ }^{24}$ Leibniz-Clarke Correspondence, p. 14. In 17th-century theological parlance these notions corresponded to God's "ordinary" and "absolute powers" (or “concourse"); see McGuire, "Boyle's Conception of Nature," p. 526.

${ }^{25}$ Leibniz-Clarke Correspondence, pp. 20, 22. The classic account of Leibniz's principle of sufficient reason is Arthur O. Lovejoy, The Great Chain of Being (Cambridge, Mass.: Harvard Univ. Press, 1936), Ch. V.

${ }^{26}$ Isaac Newton, Optice (London, 1706), pp. 345-346; quoting Query 31, Newton, Opticks (2nd ed., London, 1718), p. 378. See in this connection Kubrin, "Newton and the Cyclical Cosmos."

${ }^{27}$ Clarke, Being and Attributes of God, p. 571.
} 
original perfect design: "the wisdom and foresight of God, consist . . . in contriving at once, what his power and government is continually putting into actual execution.",28

Three important issues in metaphysics and natural philosophy were closely linked to the voluntarist-intellectualist cleavages evident in the Clarke-Leibniz exchanges: first, the question of God's knowledge and direction of the natural world; second, the question of a plenum versus a vacuum; and third, the question of the properties of matter. As we have seen, Newton specified absolute time and space as necessary attributes of God, thus making matter ontologically contingent upon the exercise of God's will. In the Queries to the 1706 Optice Newton had invited a reading which equated absolute space with God's "sensorium." ${ }^{29}$ Leibniz accepted the apparent invitation. Newton stood convicted as a materialist by his own words; Newton's God, Leibniz told Clarke, "stands in need of [an] organ to perceive things by." Newton was to be tarred with the same brush Leibniz applied to Locke. ${ }^{30}$

The problem arose from the Newtonians' desire for a God who was immanent enough in the natural world to know it intimately, to sustain its routine operations, and to suspend or alter them as he willed. However, as with the Cambridge Platonists, such a conception could without due care slide into one of God as "the soul of the world"- - a notion to which the Newtonian voluntarist tradition was, for reasons we shall see, unremittingly hostile. ${ }^{31}$ Hence, if it could be shown that Newton's conception of absolute space as God's sensorium rendered God immanent in the world, then it might be argued that the Newtonians actually held the very doctrine to which they averred repugnance. Leibniz attempted so to argue. A rightly understood God, Leibniz said, is intelligentia supramundana: "Will they say, that he is intelligentia mundana; that is, the soul of the world? I hope not." Clarke sprang to Newton's defense; Newton, he claimed, only referred to space as God's sensorium in a metaphorical sense, but how else could God volitionally affect the world's workings than by his immanence? "Nothing can any more act, or be acted upon, where it is not present; than it can be, where it is not." 32 In fact, Clarke had been defending such a conception of God's immanence for years. In his 1704-1705 Boyle lectures he insisted that God had no corporeal properties whatever, and in a sermon preached before the queen in 1711 he stressed the metaphorical nature of any reference to the passions or corporeal organs of a God "who, in reality, without Shape or Figure is in all Places every where alike Present. ...", 33

${ }^{28}$ Leibniz-Clarke Correspondence, pp. 22-23.

${ }^{29}$ See Queries 20, 23 of Newton, Optice, pp. 315, 346; Queries 28, 31 of Newton, Opticks (1718), pp. 345, 379. The question of a variant version of the Optice which might have affected Leibniz's reading is explored in Koyré and Cohen, "Case of the Missing Tanquam," but note the erroneous reference there to a 24th Query in the 1706 text.

${ }^{30}$ Leibniz-Clarke Correspondence, p. 11; see Leibniz to Bernoulli, 27 May 1716, where he comments on this aspect of the Clarke correspondence and says that "today space is the idol of the English": Correspondence of Newton, Vol. VI, pp. 353-357, on p. 356.

${ }^{31}$ For Boyle's argument against construing God as anima mundi see Boyle, "A Free Inquiry," esp. p. 363; Henry More admitted a "soul of the world," but rigorously distinguished it from God himself: The Immortality of the Soul (London, 1662), Ch. XVI. Clarke's Boyle lectures are full of remarks hostile to those representing God as the soul of the world.

${ }^{32}$ Leibniz-Clarke Correspondence, pp. 19, 21-22.

${ }^{33}$ Clarke, Being and Attributes of God, p. 540; Samuel Clarke, "Sermon Preach'd before the Queen, 7th of January, 1710-11," in Sermons, ed. John Clarke, 11 vols. (7th ed., London, 1749), Vol. XI, pp. 101-117, on pp. 108-109; cf. Clarke, "Of the Spirituality of God," in ibid., Vol. I, pp. 26-27. For relevant passages in Newton's own writings which may have been responses to 
Leibniz and the Newtonians also clashed on the quantity of matter in the universe. Leibniz maintained that the cosmos was full of matter and that Newtonian action-at-a-distance gravitation was impossible on both physical and theological grounds. When Leibniz charged the Newtonian schema with giving aid and comfort to materialists, Clarke responded that Newtonianism proved "matter, or body, to be the smallest and most inconsiderable part of the universe." Almost the whole universe was free of matter, a theater for the play of active forces. To Leibniz, however, the more matter the merrier; the more there is "the more God has occasion to exercise his wisdom and power. Which is one reason, among others, why I maintain that there is no vacuum at all." A vacuum in nature amounts to an imperfection: an aspersion cast against God's wisdom. Clarke responded that a void has no affect on God's wisdom and has the advantage of providing greater scope for the action of his will, for in that void work the active forces, the delegates of that will. The greater their role in natural philosophy, the greater the role for God's providential will. ${ }^{34}$

Finally, the Leibniz-Clarke exchanges manifested radically divergent conceptions of the nature of matter and its properties. The conflict hinged upon whether matter was to be conceived of as inanimate, devoid of inherent properties of activity, motion, and sentience (as the Newtonians maintained), or whether it was construed as essentially active and sentient (as in Leibniz's metaphysics). Apart from the issue whether gravity was inherent in matter, the question of matter theory was largely implicit in the exchanges themselves. Yet matter theory was of fundamental importance to conceptions of God's attributes and his relationship to the natural world. The Newtonian heritage, deriving as it did from Boyle's corpuscularianism and the Cambridge Platonists' philosophy of God and nature, was predicated upon a view of matter as "brute and stupid." 35 If matter could not move itself or arrange its own patterned motions, then it must be God who causes it ultimately to do so. An immanent God was more than a First Cause, for he continually sustains the patterns of activity in the world. If, as Boyle and the Newtonians maintained, substance is devoid of inherent properties of activity, motion, or sentience, then individual existents can have no inherent connections with each other and natural laws are imposed from without, by the will of God. In the Newtonian schema brute matter and God's providential will were complementary concepts. ${ }^{36}$ Contrastingly, Leibnizian appreciations of God's supreme wisdom and the preestablished harmony of the universe were founded on views of matter as ultimately active and sentient. By positing inherent qualities of motion

Leibniz's criticisms see Newton, Principia (1726), p. 529; Newton, Mathematical Principles of Natural Philosophy (1729), Vol. II, p. 391; Newton, Opticks (1718), p. 379. See also I. Bernard Cohen, Introduction to Newton's "Principia" (Cambridge, Mass.: Harvard Univ. Press, 1971), pp. 243n, 250-251.

${ }^{34}$ Leibniz-Clarke Correspondence, pp. 12, 16, 21; cf. Arnold Thackray, “'Matter in a Nut-Shell': Newton's Opticks and Eighteenth-Century Chemistry," Ambix, 1968, 15:29-53; Thackray, Atoms and Powers: An Essay on Newtonian Matter-Theory and the Development of Chemistry (Cambridge, Mass.: Harvard Univ. Press, 1970), pp. 53-67; J. E. McGuire, "Force, Active Principles, and Newton's Invisible Realm,' Ambix, 1968, 15:154-208.

${ }^{35}$ This heritage is delineated and its ideological significance traced by J. R. Jacob, Robert Boyle and the English Revolution (New York: Burt Franklin, 1977); M. C. Jacob, Newtonians; J. R. Jacob and M. C. Jacob, "The Anglican Origins of Modern Science: The Metaphysical Foundations of the Whig Constitution," Isis, 1980, 71:251-267; and Shapin, "Social Uses of Science."

${ }^{36}$ For an excellent comparison of Boyle and Leibniz on this subject see McGuire, "Boyle's Conception of Nature," pp. 524-528. 
and "perception" in his monads, Leibniz made them self-sufficient entities, independent of God's continuing superintendence. Since they were themselves "the sources of their internal actions" and since they possessed inherent relational attributes, monads contained the basis of the preestablished harmony of the world. God's wisdom, in his original perfect plan, created the monads so that natural laws were the working out of the inherent qualities of substance through the interconnections of things. ${ }^{37}$ In such an antinominalist schema there was little scope for the exercise of providential will so valued by the Newtonians.

\section{THE NEWTONIANS' DOMESTIC ENEMIES}

By the time of the 1715-1716 exchanges with Leibniz, most of Clarke's arguments in favor of the Newtonian world view had a considerable history behind them. ${ }^{38}$ They had been developed and deployed, by Clarke and other apologetic writers, in an attempt to secure Christianity against threats from its perceived enemies. The major site of this joint defense of Newtonianism and Christianity was, as Margaret Jacob has shown, the lecture series founded in 1691 by Robert Boyle for "proving the Christian Religion, against notorious Infidels." 39 The enemies of proper Christianity were explicitly identified. In the first of the series, preached in 1692, the Reverend Richard Bentley argued against those writers who maintained that mere matter and motion were capable of producing the phenomena of sentience. Twenty years later, in Bentley's Remarks upon a Late Discourse of Free-thinking, he mounted a frontal attack on the views of Anthony Collins and John Toland. In 1698 the Reverend John Harris set about to confute modern "Hobbists" and "Spinozists," who denied the reality of spirit or who conceived of matter as active; special opprobrium was reserved for Charles Blount. The Reverend Samuel Clarke's Boyle lectures of 1704-1705 were labeled as an "answer to Mr. Hobbs, Spinoza, and their followers." These followers were named as Toland and Charles Blount. Later, as the LeibnizClarke exchanges were concluding, Clarke published a vehement denunciation of a work by Collins denying human liberty. In the Boyle lectures of 1713-1714 the Reverend Benjamin Ibbot inveighed against the irreligious tendencies of modern English free-thought, singling out Anthony Collins for particular odium theologicum. Nor were these the only writers with Newtonian affiliations to attack the views of Blount, Collins, and Toland: George Cheyne, John Keill, John Maxwell, and John Hancock also figured prominently. ${ }^{40}$

\footnotetext{
${ }^{37}$ For Leibniz's views of substance see J. E. McGuire, “'Labyrinthus Continui': Leibniz on Substance, Activity, and Matter," in Peter K. Machamer and Robert G. Turnbull, eds., Motion and Time, Space and Matter (Columbus, Ohio: Ohio State Univ. Press, 1976), pp. 290-327; Ian Hacking, "Individual Substance," in Harry G. Frankfurt, ed., Leibniz: A Collection of Critical Essays (Notre Dame, Ind.: Univ. Notre Dame Press, 1976), pp. 137-153; see also n. 85.

${ }^{38}$ Hall, Philosophers at War, p. 232, notes this fact, but seems to think that this diminishes the significance of the metaphysical and natural-philosophical controversies.

${ }^{39}$ M. C. Jacob, Newtonians, Chs. IV $-\mathrm{V}$.

${ }^{40}$ Bentley, Matter and Motion Cannot Think; Richard Bentley, Remarks upon a Late Discourse of Free-thinking . . . , in Works, Vol. III, pp. 287-474; John Harris, The Atheistical Objections, against the Being of a God, and His Attributes, Fairly Considered, and Fully Refuted (London, 1698), Sermon I, p. 20; Sermon II, pp. 5-8; Sermon III, pp. 4-6, 16, 25, et passim (after about 1706 Harris's position moved closer to Toland's: see Geoffrey Bowles, "John Harris and the Powers of Matter," Ambix, 1975, 22:21-38); Clarke, Being and Attributes of God, pp. 531-535, 544; John Clarke, Remarks upon a Book, entituled, Philosophical Enquiry Concerning Human Liberty (London, 1717); Benjamin Ibbot, A Course of Sermons Preach'd for the Lecture Founded by the Honourable Robert
} 
What were the views which proved so repugnant to Anglican Newtonians of the period? Of what possible relevance to the 1715-1716 Leibniz-Clarke exchanges is the conflict between these groups? The circle of late seventeenth- and early eighteenth-century English writers which included Charles Blount (1654-1693), Anthony Collins (1676-1729), William Coward (1657-1725), Matthew Tindal (1657-1733), and John Toland (1670-1722) tended to style themselves freethinkers. Their opponents variously characterized them as freethinkers, deists, atheists, Socinians, Hobbists, Spinozists, and "Hereticks." It is risky to construct a group portrait of this circle: they differed from one another on some points, and individual members changed and developed their philosophies over time. Nevertheless, certain stable features of their writings are noticeable, especially as these were the features that Clarke, Bentley, Ibbot, and others uniformly attributed to them and that their enemies regarded as especially odious and worthy of condemnation. ${ }^{41}$

First, the freethinkers rejected the Newtonian insistence upon a conception of matter as "brute and stupid." As Toland wrote in his Letters to Serena, ". . . Matter is necessarily active as well as extended"; ". . . all the Matter in Nature, every Part and Parcel of it, has bin ever in motion, and can never be otherwise. ${ }^{42} \mathrm{By}$ conjoining the idea of matter with the idea of activity, and by stipulating the eternality of that motion, Toland eroded the Newtonian notion of God as the First Cause of activity. Secondly, the inherent activity of matter was extended to encompass its inherent sentience. Collins maintained that matter, suitably arranged, might be able itself to produce thought. Toland went further. By the time of his 1720 Pantheisticon, he had adopted a full-blown pantheistic materialism in which matter, with its inherent properties, was the only entity in the cosmos. ${ }^{43}$

Boyle, Esq; at the Church of St. Mary le Bow, in the Years 1713 and 1714 (London, 1727), Pt. I, pp. 44, 50, 87-88, 211-213, et passim. Among other Boyle lectures, see William Derham, PhysicoTheology: or A Demonstration of the Being and Attributes of God, from His Works of Creation (London, 1713); Francis Gastrell, "The Certainty and Necessity of Religion in General . . . ," in $A$ Defence of Natural and Revealed Religion [a collection of Boyle lectures 1691-1732], 3 vols. (London, 1739), Vol. I, pp. 275-352, on p. 288; John Hancock[e], "Arguments to Prove the Being of God . . . ," in ibid., Vol. II, pp. 197-258, on pp. 202, 215, 257. Also George Cheyne, Philosophical Principles of Natural Religion (London, 1705), Dedication, Sig. A4r ; John Keill, An Examination of Dr. Burnet's Theory of the Earth (Oxford, 1698), pp. 36-37; John Maxwell, "A Summary of the Controversy between Dr. Samuel Clarke and an Anonymous Author, Concerning the Immateriality of Thinking Substance," Appendix to Richard Cumberland, A Treatise of the Laws of Nature, trans. Maxwell (London, 1727).

${ }^{41}$ Their major works include Charles Blount, Anima Mundi and The Oracles of Reason, both in The Miscellaneous Works of Charles Blount, Esq. (London, 1695); W[illiam] C[oward], The Grand Essay: or a Vindication of Reason, and Religion, against the Impostures of Philosophy (London, 1704); Anthony Collins, A Discourse of Freethinking (London, 1713); Collins, A Philosophical Inquiry Concerning Human Liberty (London, 1717); Matthew Tindal, The Rights of the Christian Church (London, 1707); John Toland, Letters to Serena (London, 1704), and others cited below. Good sources on the English deists include M. C. Jacob, Newtonians, Ch. VI; M. C. Jacob, The Radical Enlightenment: Pantheists, Freemasons and Republicans (London: Allen \& Unwin, in press); Alfred Owen Aldridge, Shaftesbury and the Deist Manifesto (Philadelphia: American Philosophical Society, 1951); Roland N. Stromberg, Religious Liberalism in Eighteenth-Century England (London: Oxford Univ. Press, 1954); John Redwood, Reason, Ridicule, and Religion: The Age of Enlightenment in England 1660-1750 (Cambridge, Mass.: Harvard Univ. Press, 1979); Redwood, "Blount, Deism and English Free Thought," J. Hist. Ideas, 1974, 35:490-498. One of the best brief contemporary summaries of the "principles of atheism" is Ibbot, Course of Sermons, Pt. II, p. 75.

${ }^{42}$ Toland, Letters to Serena, pp. 164, 167; cf. similar views in Coward, Grand Essay, esp. pp. $152-153$.

${ }^{43}$ Anthony Collins, Reflections on Mr. Clark's Second Defence of His Letter to Mr. Dodwell (London, 1707), p. 24; John Toland, Pantheisticon: or, the Form of Celebrating the Socratic-Society, trans. anon. (London, 1751; 1st ed., 1720). For more on Toland and pantheistic materialism see 
There was simply no need for external spiritual agencies to animate a sluggish material world, for the freethinkers did not conceive of matter as inanimate. Insofar as they did admit a God recognizable as such by more orthodox Christians, it was God as anima mundi; there was no God distinct from nature. ${ }^{44}$ And even those freethinkers who disowned such a conception were accused of pantheistic materialism by their Anglican enemies. Thirdly, the freethinkers argued that proper religion was rational; there were no "mysteries" associated with Christianity save those introduced by corrupt priests. Toland's Christianity Not Mysterious and Blount's Oracles of Reason were the earliest shots fired in the freethinkers' campaign against elements of established religion in England. From 1707 Collins was arguing for the autonomy and supremacy of reason in all intellectual inquiries, especially religion; he asserted that authority worked solely to fetter and corrupt proper religious understanding, and he denied the role of revelation. In 1707 and 1708 Collins mischievously joined forces with the nonjuring Henry Dodwell to dispute with Samuel Clarke the role of reason in religion and the mortality of the soul. ${ }^{45}$ Fourthly, the freethinkers espoused the view that human actions were not free but were, rather, the outcomes of necessity. Thus Collins's Philosophical Inquiry Concerning Human Liberty (a book which Priestley said converted him to determinism) argued that free will is an illusion and that, in fact, even our commonsense experience of action provides testimony to moral necessity. ${ }^{46}$ Finally, insofar as the freethinkers' natural order actually required a Deity, it was based upon a God who framed an original all-wise and immanent design rather than upon one who intermittently had to exercise his providential will. One can see how this conception of the Deity was built into the freethinkers' cosmology: if matter were indeed inherently imbued with activity and sentience, then the patterned phenomena of nature could be accounted for by principles immanent in itself; there was simply no need for external animating agencies or the imposition of activity and order from without. Anglican apologists, quite understandably, saw little difference between the freethinkers' God and no God at all. ${ }^{47}$

M. C. Jacob, "Newtonian Science and the Radical Enlightenment," Vistas in Astronomy, 1979, 22:545-555; M. C. Jacob, Radical Enlightenment.

${ }^{44}$ See, e.g., Coward, Grand Essay, for an attack on immaterial substances in general. The explicit identification of God as "the soul of the world" was in fact rarely professed during this period. Anima mundi beliefs, like atheism, are perhaps best understood as a tendency and as an accusation: freethinkers were accused of conceiving God to be "the soul of the world"; some of them actually did so. Leibniz was inclined to accuse the Newtonians of this view, knowing it would damage their case; and Newton and Clarke were as keen to suggest that both Leibniz and the freethinkers recommended this notion of the Deity. In practice, any tendency to restrict God's providence or to make him immanent in the natural world ran the risk of drawing this stigma. Hence, all parties were vulnerable to some degree.

${ }^{45}$ John Toland, Christianity Not Mysterious (London, 1696), which capitalized on John Locke, The Reasonableness of Christianity (London, 1695); Blount, Oracles of Reason; Anthony Collins, An Essay Concerning the Use of Reason in Propositions (London, 1707); Collins, A Reply to Mr. Clark's Defence of His Letter to Mr. Dodwell (London, 1707); for the Collins-Clarke-Dodwell disputes see James O'Higgins, Anthony Collins: The Man and His Works (The Hague: Martinus Nijhoff, 1970), Ch. V.

${ }^{46}$ Collins, Philosophical Inquiry Concerning Human Liberty, esp. pp. 71-75, where Collins argues against human liberty on the basis of God's prescient wisdom. An insoluble problem results, he says, from maintaining that man is free and that God is all-knowing. Since God must be all-wise and allforeseeing, then man cannot freely choose his actions. See also O'Higgins, Collins, p. 97n.

${ }^{47}$ For a typical expression of this, see Harris, Atheistical Objections, Sermon II, p. 7: "if they make him such an Impotent and Careless Being, as either cannot or will not govern the World, give Laws to his People, vindicate his own Honour, and punish and reward Men according to their Actions: ... in reality they deny him. ..." 
It should be evident from even this brief sketch that there were crucial cosmological resources which were shared between the English freethinkers and Leibniz. These links are apparent both from the texts themselves and from Anglican Newtonians' responses to each. It is possible that Clarke and his colleagues saw more than intellectual similarities between Leibniz and the freethinking canon: they may have perceived substantive connections. John Toland's mysterious missions to Hanover and Berlin in 1701 and 1702 (possibly as a spy), when he conveyed the Act of Settlement to the Hanoverian court, were widely publicized in England. He met and conversed with Leibniz at this time and again in 1707. Before the publication of Leibniz's Theodicy in 1710, Toland read the proofs in Amsterdam. In 1708 Toland was apparently boasting of his contacts with Leibniz, and both were known to have important links to the court of Eugene of Savoy. Toland and Leibniz agreed that they shared certain goals, such as the desire to "crush superstition" and securely establish the Hanoverian succession, even though it is quite clear that Leibniz heartily disapproved of Toland's developing pantheism. ${ }^{48}$ There is no doubt Anglican Newtonians perceived similarities between Leibniz's philosophy and that of English deists and freethinkers. ${ }^{49}$ What is neither a valid inference nor necessary to the present interpretation is that Leibniz and the English freethinkers had the same purposes in constructing their world views.

This brief account of the perceived similarities between Leibniz's views and those of Collins, Toland, and others does not purport to make Leibniz into an actor on the English political stage, even though, as we have seen, it is important to bear in mind that his interests were bound up with the course of the Hanoverian succession. Nonetheless the content and course of the Leibniz-Clarke controversies cannot be properly understood without recognizing that they were situated in the political context of preexisting disputes between Anglican Newtonians and their indigenous disloyal opposition. The conflicts in natural philosophy and metaphysics have to be referred to the concrete social and political interests of the groups using these sorts of culture as apologetic resources.

\footnotetext{
${ }^{48}$ M. C. Jacob, Newtonians, p. 230; F. H. Heinemann, "Toland and Leibniz," Philosophical Review, 1945, 54:437-457; Lord Raby to Leibniz, 29 Dec. 1707, and Leibniz to Toland, 30 Apr. 1709, both in Kemble, State Papers, pp. 464-465, 467-470; also G. W. Leibniz, "Annotatiunculae subitaneae ad librum de Christianismo Mysteriis carente: Conscriptae 8 Augusti 1701," in A Collection of Several Pieces of Mr. John Toland, 2 vols. (London, 1726), Vol. II, pp. 60-76. Heinemann, "Toland and Leibniz," argues that the contacts between the two provide evidence that Leibniz "influenced" Toland, a view which is rejected by M. C. Jacob, Newtonians, p. 231n. The present argument is not that Leibniz "influenced" Toland, but that the two were perceived to utilize common philosophical resources: a perception which was reinforced by the knowledge of contacts between them.

${ }^{49}$ See the accounts of similarities between Leibniz's and Collins's views in O'Higgins, Collins, pp. 97, 99-102, 106-107; Clarke, Remarks upon a Book, bound with John Clarke, A Collection of Papers, which Passed between the Late Learned Mr. Leibnitz, and Dr. Clarke, in the Years 1715 and 1716. That a connection was perceived between the Leibniz-Clarke exchanges and the Collins-Clarke exchanges appears from a letter from Collins to Desmaizeux, who was editing the Leibniz-Clarke papers: "Let not the collection of Leibniz's and Clarke's Papers etc. now printing in Holland wait for my reply to Dr. Clarke." (British Library MSS Add. 4282, fol. 150, 17 June 1718; quoted in M. C. Jacob, Radical Enlightenment.) It has been suggested that Leibniz thought highly of Hobbes's metaphysics and physics and was indebted to him for his concepts of conatus and monads; whether these similarities were widely perceived remains to be investigated. See J. W. N. Watkins, Hobbes's System of Ideas: A Study in the Political Significance of Philosophical Theories (New York: Barnes \& Noble, 1968), pp. 125-132; Howard R. Bernstein, "Conatus, Hobbes, and the Young Leibniz," Studies in History and Philosophy of Science, 1980, 11:25-37.
} 


\section{WHIG AND TORY, COURT AND COUNTRY: IDEOLOGIES OF ORDER}

The invitation to consider the Leibniz-Clarke metaphysical and natural philosophical conflicts in the context of English political affairs comes from the participants themselves. In Clarke's reply to Leibniz's first paper the English divine commenced by identifying the universe of the perfectly working clock as "the notion of materialism and fate," tending "to exclude providence and God's government in reality out of the world." He continued:

And by the same reason that a philosopher can represent all things going on from the beginning of the creation, without any government or interposition of providence; a sceptic will easily argue still further backwards, and suppose that things have from eternity gone on (as they now do) without any true creation or original author at all, but only what such arguers call all-wise and eternal nature. If a king had a kingdom, wherein all things would continually go on without his government or interposition, or without his attending to or ordering what is done therein; it would be to him, merely a nominal kingdom; nor would he in reality deserve at all the title of king or governor. And as those men, who pretend that in an earthly government things may go on perfectly well without the king himself ordering or disposing of any thing, may reasonably be suspected that they would like very well to set the king aside: so whosoever contends, that the course of the world can go on without the continual direction of God, the Supreme Governor; his doctrine does in effect tend to exclude God out of the world.

\section{Leibniz rose to the bait:}

The comparison of a king, under whose reign every thing should go on without his interposition, is by no means to the present purpose; . . . . 'Tis just as if one should say, that a king, who should originally have taken care to have his subjects so well educated, and should, by his care in providing for their subsistence, preserve them so well in their fitness for their several stations, and in their good affection towards him, as that he should have no occasion ever to be amending any thing amongst them; would be only a nominal king.

It would appear from these passages that Leibniz and Clarke had radically differing conceptions of proper kingship. It would also appear that Clarke was pointing towards elements within English society whose notions of political order were dangerously threatening. In Clarke's dedication of the 1717 publication of the exchanges to Princess Caroline he makes the political context of metaphysical conflict even more concrete:

By the Protestant Succession in the illustrious house of Hanover having taken place, this nation has now . . . a certain prospect, (if our own vices and follies prevent not) of seeing government actually administered, according to the design and end for which it was instituted by providence. . . . We have a prospect of seeing the true liberty of a brave and loyal people, firmly secured, established, and regulated, by laws equally advantageous both to the crown and subject. . . . What views and expectations less than these, can a nation reasonably entertain; when it beholds a King firmly settled upon the throne of a wisely limited monarchy, whose will, when without limitation, showed always a greater love of justice, than of power; and never took pleasure in acting otherwise, than according to the most perfect laws of reason and equity? ${ }^{50}$

Although the participants invite us to consider the political setting of natural

${ }^{50}$ Leibniz-Clarke Correspondence, pp. 14, 19-20, 7. 
philosophical and metaphysical disputation, it may be that such usages were "merely metaphorical," that the references to "kingship" were figures of speech designed to render generally comprehensible messages that functioned solely within an autonomous scientific context. This objection can be met by situating the actors and their discourse within the relevant political settings, then demonstrating how the cultures of natural philosophy and metaphysics were routinely employed to comment upon the social and political orders and to defend concrete social interests.

Political discourse in England from the 1680s to the 1720s was fundamentally structured by the great events of monarchical succession and the attendant debates on the nature of royal legitimacy and political obligation. By what right did James II, William and Mary, Anne, and George I occupy the throne? What scope did they have in the exercise of monarchical power? How did that power relate to the rights and liberties of "people" and Parliament? What were the duties of the people to the monarch and of the monarch to those he ruled? Abstract political writings, theories of the state and of obligation, always bore upon concrete political events and possible courses of practical political action, such as those involved in the Glorious Revolution, the debate on toleration, the Act of Settlement, the Triennial Act, the issues raised by the Sacheverell trial, and the relations of church and state. English political thought in this period was thought about actual or contemplated political action in respect of the distribution of power in the state and social institutions; and it tended to focus upon the questions of royal legitimacy and power. The resources used to address these political questions included theology and natural philosophy as well as direct political comment. As Margaret Jacob and others have shown, the "world natural" and the "world politick" were connected by a web of religious meaning. ${ }^{51}$ In the late seventeenth and early eighteenth centuries the political order was not taken to be distinct from the sacred and natural orders. Monarchy stood in some relationship to the Deity, even though the precise nature of that relationship was violently disputed. Likewise, the natural world was seen to be part of God's order and full of moral significance, although here too there was intense debate over how to conceive God's role in the creation of the world and its continuing functioning. The cultures of theology, politics, and natural philosophy overlapped because they were connected in legitimations, justifications, and criticisms, especially in the use of conceptions of God and nature to comment upon political order.

Debates over the scope of monarchical will in particular throw new light on the significance of such usages for contemporary natural-philosophical controversies. From the Restoration until the accession of the house of Hanover English political sentiments were divided among parties (or elements) which often expressed different and conflicting views of the role of kingship in the state. One cleavage is apparent in contrasting "Tory" and "Whig" ideologies of political order. ${ }^{52}$ In

\footnotetext{
${ }^{51}$ M. C. Jacob, Newtonians; J. R. Jacob, Robert Boyle. See Shapin, "Social Uses of Science," for a discussion of the ideological significance of these connections.

${ }^{52}$ One has to be quite careful not to reify the notion of "political party": early 18th-century parties did not exist in anything like the organizational form of modern parties, and their ideological stances often converged on specific issues, even while they continued to represent different "constituencies." The best modern sources for parties and their ideologies in this period are: H. T. Dickinson, Liberty and Property: Political Ideology in Eighteenth-Century Britain (New York: Holmes and Meier, 1977), Chs. I-II; J. P. Kenyon, Revolution Principles: The Politics of Party 1689-1720 (Cambridge: Cambridge Univ. Press, 1977); and J. G. A. Pocock, The Machiavellian Moment: Florentine Political
} 
the classic Tory formulation monarchy was properly absolute; the king ruled by divine right and was God's vice-regent; hereditary succession was indefeasible and divinely sanctioned; the king's subjects had no right actively to resist his will, just as they had no right to defy God's commands; and subjects had the right to passive resistance only when the king had manifestly flouted the laws of God (and even then they were obliged to accept the earthly consequences of such defiance). The political alternative to absolute monarchy was, in the classic Tory view, "the mob," a concrete example of which could be found in regicide and the Civil War decades. Any limits on absolute monarchy or any basis for royal authority less than divine led inexorably to chaos. Among the resources Tories invoked in support of their ideology of order were scripture, history, and the natural order. The relationship between God and the monarch was direct; kings were God's viceregents and ruled by his will. After 1688-1689 many Tories experienced a crisis of conscience; William and Mary were not, in their eyes, legitimate monarchs, divinely ordained and ruling by indefeasible hereditary right. But the alternative to them was dangerous, risking further civil war and threats to the rights of the landed classes which adhered to Tory ideology. One Tory solution was de facto theory, by which it was acknowledged that William and Mary were de facto rulers, to whom allegiance could be given, without prejudice to James II's (and later "James III's") de jure rights to the throne. ${ }^{53}$ Another solution, albeit not particular to the Tories, invoked the notion of God's providential will in the world to justify the actual succession and subjects' continuing duty to submit to royal commands. God's particular providence and special will accounted for the events of 1688-1689 and justified their outcome. For similar reasons, and through the use of similar resources, most Tories supported the 1701 Act of Settlement which placed the elector of Hanover in line of succession, although some Tories were indeed plotting the return of the Stuarts right up to 1714 and beyond. Although they underwent a severe buffeting by the successional convolutions of 1688 and 1714, Tory principles were adjusted and adapted, in general replacing the sovereign and irresistible power of the absolute monarch with that of king and Parliament. Like the Vicar of Bray, most Tories bent their political philosophy with the prevailing wind. ${ }^{54}$ The basic social investments of men of substantial landed property could only be made secure within a stable and hierarchical social order, even if the particular post-Revolution version of stability and hierarchy was not precisely to Tories' taste. ${ }^{55}$

Opposed to this was the classic Whig ideology of order, legitimacy, and obligation. Absolute monarchy was rejected in principle; monarchical will was properly limited by law; succession did not depend upon indefeasible hereditary right but upon some sort of contract with the political nation; the relationship between God and any particular monarch was not direct but mediated. Most importantly, the people (and their parliamentary representatives) had the right to resist the commands of a monarch who threatened to overstep the limits placed upon his power. Because William and Mary replaced the absolutist tendencies of James II

Thought and the Atlantic Republican Tradition (Princeton, N.J.: Princeton Univ. Press, 1975), Pt. III, from which the following paragraphs are largely drawn.

${ }^{53}$ On de facto theory, see esp. Kenyon, Revolution Principles, Ch. III.

54 "When William our deliverer came,/ To heal the nation's grievance,/ I turned the cat in pan again,/ And swore to him allegiance ...": The Vicar of Bray, anonymous 18th-century poem.

${ }^{55}$ Dickinson, Liberty and Property, pp. 36-44. 
and because the Hanoverians were meant to forestall the return of a Stuart backed by the absolutist Louis XIV, the Whigs supported the Glorious Revolution and worked to secure the Protestant succession. Indeed, that was in large measure what defined a Whig. Whigs supported a limited version of monarchy, but they also upheld the rights of particular post-Revolution monarchs. Whigs no less than Tories wished that monarchy should stand as a bulwark against the threat of the mob. For the Whigs were no democrats and even John Locke spoke for no more than a very few of them. They too were men of property and had clear interests in the maintenance of hierarchy and due submission of ranks.

A simple account of party and ideology in this period would then point to Tories stressing the unlimited will of the monarch and Whigs working towards its limitation. However, at least three refinements and modifications of that picture have to be introduced to obtain anything like a satisfactory understanding of how political philosophies were distributed: first, the ecclesiastical divisions so closely connected to party politics; second, the interests of "Court" and "Country" elements which cut across Whig and Tory parties; and third, the effects upon party ideology of the fine structure of politics from the Revolution to the succession of George I.

Severe strains were put upon the Church of England by the 1688 Revolution and ensuing events. Traditionally, Anglican divines had offered a religious interpretation of political obligation; all legitimate authority arose from God's providence and all disobedience of rightful authority had the character of sin. ${ }^{56}$ But after 1688-1689 a significant fraction of the clergy refused to acknowledge the legitimacy of William and Mary (the nonjurors), and many others felt their principles to be compromised. Moreover, the new order threatened the basis of clerical authority in society. Early in William's reign the Toleration Act removed much of the burden on Dissenters and the growing practice of occasional conformity removed still more. The expiration of the Licensing Act let loose a flood of anticlerical and deistical writing, and the diminishing authority of ecclesiastical courts eroded the ability of the church to punish the immoral. The church split over how to deal with these developments and what posture to adopt towards the post-Revolution crown that permitted them. The bishops (constituting the Upper House of Convocation) tended towards latitudinarianism and Erastianism. ${ }^{57}$ They upheld the legitimacy of the post-Revolution monarchy; supported a large measure of toleration; feared Rome more than Dissent; and maintained that the church was properly subordinate to state authority. Contrastingly, the parsons (who made up the Lower House of Convocation) tended towards a High Church philosophy which bemoaned $1688-1689$ as devastating proper principles of nonresistance and the jus divinum; abominated occasional conformity and advocated a hard line on Dissent and deism; asserted a proper equality of state and church;

${ }^{56} \mathrm{G}$. V. Bennett, The Tory Crisis in Church and State 1688-1730: The Career of Francis Atterbury Bishop of Rochester (Oxford: Clarendon Press, 1975), p. 6. See also Bennett, "Conflict in the Church," in Geoffrey Holmes, ed., Britain after the Glorious Revolution 1689-1714 (London: Macmillan, 1969), pp. 155-175; Kenyon, Revolution Principles, Chs. V-VI, VIII; Stromberg, Religious Liberalism, Chs. VII-VIII; Gerald M. Straka, Anglican Reaction to the Revolution of 1688 (Madison, Wisc.: State Historical Society, 1962); and Norman Sykes, Church and State in England in the XVIIIth Century (Cambridge: Cambridge Univ. Press, 1934).

${ }^{57}$ G. R. Cragg, From Puritanism to the Age of Reason: A Study of Changes in Religious Thought within the Church of England 1660-1700 (Cambridge: Cambridge Univ. Press, 1950), Chs. IV, VIII-IX; Stromberg, Religious Liberalism, Ch. IX; Sykes, Church and State, Chs. VII-VIII; M. C. Jacob, Newtonians, Ch. I. 
bridled at the authority of the bishops and rejected their latitudinarianism. ${ }^{58}$ Some of them professed continuing loyalty to the Stuarts (despite their Catholicism) and worked for a reunion with Rome. The party-political significance of these ecclesiastical divisions was not lost upon contemporary observers; a 1704 pamphlet put it bluntly: "all this noise about High and Low Church . . . signifies no more than Whig and Tory." ${ }^{59}$ Indeed, High Church principles found their greatest support among Tory squires while the Low Church latitudinarian bishops spoke for traditional Whig constituencies. The accession of Anne, a good churchwoman, raised High Church hopes, but her dislike of faction forced their spokesmen out of office, and then High Church agitation developed in opposition to the queen and her ministers. Around 1705 the Tory High Churchmen raised the cry of "the Church in danger" and in 1709 they rallied around Sacheverell in his rant against Dissent, Erastian tendencies, and the anti-passive-obedience ideology of the Whig bishops. The success of High Church Tories in mobilizing public support badly frightened the Whig bishops, and, from about 1710, their doctrine began to converge with that of the Tories, particularly in their endorsement of passive obedience to the monarch. ${ }^{60}$

Ecclesiastical conflicts between High and Low Church orientations helped to polarize divisions between Court and Country parties. ${ }^{61}$ Particularly after 1689 and the commencement of William's wars with France, the political nation was divided on the questions of what the financial, military, and patronage powers of the crown ought to be. The increased size of the army and the mobilization of resources to finance it vastly augmented court patronage. Within both Whig and Tory parties there were elements which either supported the prerogatives of court power or wished to see that power strictly limited. Junto Whigs as well as Tory ministers under William and Anne worked to persuade parliamentarians that their particular interests depended upon giving support for the power of the crown and its ministers. In both Whig and Tory parties there were many who realized that their goals could only be furthered by maintaining influence at court and by advocating greater scope for monarchical power. Tory elements were historically disposed to support royal prerogatives, even if many of them questioned the legitimacy of William and Anne. Whig elements, while traditionally disinclined to celebrate monarchical will, nevertheless perceived the success of William's and Anne's Continental wars as vital to the security of a Protestant limited monarchy in opposition to Louis XIV's Papist absolutism. It was largely for this reason that the Whig Low Church bishops tended to have close ties with the court and to support its powers.

\footnotetext{
${ }^{58}$ For a fascinating account of High Church natural philosophy see C. B. Wilde, "Hutchinsonianism, Natural Philosophy and Religious Controversy in Eighteenth Century Britain," History of Science, 1980, 18:1-24.

${ }^{59} \mathrm{~A}$ Letter to a Friend concerning the New Distinction of High and Low Church (London, 1704), p. 19, quoted in S. L. Ollard, ed., A Dictionary of English Church History (London: A. R. Mowbray \& Co., 1912), p. 115 (Ollard provides satisfactory short definitions and histories of ecclesiastical terminology).

${ }^{60}$ Kenyon, Revolution Principles, pp. 202-203; Geoffrey Holmes, The Trial of Doctor Sacheverell (London: Eyre Methuen, 1973).

${ }^{61}$ As with Whig and Tory, it is best not to think of Court and Country as modern political parties, even though they were generally called "parties" by contemporaries. For accounts of Court and Country divisions see Dickinson, Liberty and Property, Chs. III-V; Pocock, Machiavellian Moment, Ch. XII; Geoffrey Holmes, British Politics in the Age of Anne (London: Macmillan, 1967); J. R. Jones, Country and Court: England, 1658-1714 (Cambridge, Mass.: Harvard Univ. Press, 1978); W. A. Speck, Stability and Strife: England 1714-1760 (Cambridge, Mass.: Harvard Univ. Press, 1979).
} 
Similarly, Country elements were found in both parties. Country Tories were traditionally procrown, but, as we have seen, had ideological problems accepting the legitimacy of post-Revolution monarchs. In ecclesiastical matters Country Tories tended to support the High Churchmen in their fight against the Erastian subordination of church to court. Many Country ("Old" or "Real") Whigs found it difficult after the Glorious Revolution to adjust themselves to a toadying posture; some were in a position where it was inexpedient to do so. Country ideology expressed itself in a variety of ways: paramount was a social vision of a community of virtue composed of freeholding landowners. ${ }^{62}$ Country ideology held that court and ministerial influence over Commons was corrupting; it disliked the idea of a standing army and advocated a militia of independent landowners; it was deeply suspicious of placemen and courtiers, especially in financial and commercial circles and in the military.

Some modifications of ideological patterns were occasioned by particular political circumstances from the Revolution to the succession. Of special importance was the pressure exerted on Whigs to clarify what had happened in 1688. Establishment Whigs intended 1688 to be the last revolution, hence there were obvious dangers in saying that James II had been rightly deposed and that the monarch ruled by consent of the sovereign people. Excessive stress upon the consent of the people ran the very real risk of providing a justification for another Stuart restoration. Emphasis upon Anne's hereditary right to the throne ran the same risk, for this could be construed as endorsing the Pretender's claims. Hence Court Whigs tended to opt for the theory either that James II had abdicated or that the Revolution was the working out of God's providential will, or some combination of these theories. Only the Old Whigs of the Country party were prepared fully to endorse the "Revolution Principle" of popular sovereignty. Political pressures pushing Court Whigs in the direction of positions which had been traditionally Tory became particularly intense by 1708-1711. For one thing Anne's rapid aging made it a matter of urgency that Whigs expeditiously settle their principles of legitimacy and obligation. And from the right came Tory attempts to associate all Whigs with the political views of the Country element, accusing Whigs as a whole of republican and leveling tendencies.

The thunder from the right was even more intense in ecclesiastical matters. High Church tactics portrayed the Whigs as lacking appropriate bloodlust for hunting heretics, and even discovered the occasional deistical red under the Whig bed. This was a problem which afflicted Newtonian divines particularly acutely from about 1711. In that year a controversy began to rage over the Arianism of Newton's Cambridge successor William Whiston, and Newton's own speculations on Biblical chronology were raising doubts about the great man's orthodoxy. ${ }^{63}$ But these difficulties for the Newtonian establishment were slight compared to

\footnotetext{
${ }^{62}$ This vision derived from the political writings of James Harrington, which John Toland edited in 1699 under the Earl of Shaftesbury's patronage; see J. G. A. Pocock, ed., The Political Works of James Harrington (Cambridge: Cambridge Univ. Press, 1977), esp. pp. 141-143; Pocock, "Machiavelli, Harrington and English Political Ideologies in the Eighteenth Century," Politics, Language and Time: Essays on Political Thought and History (London: Methuen, 1972), pp. 104-147; Lois G. Schwoerer, "No Standing Armies!": The Antiarmy Ideology in Seventeenth-Century England (Baltimore: Johns Hopkins Univ. Press, 1974), Chs. VIII-IX.

${ }^{63}$ Redwood, Reason, Ridicule and Religion, pp. 98, 165-167; note that Leibniz was one of those who publicly discerned atheistical implications in Newton's chronological work. For English Arianism in this period, see Stromberg, Religious Liberalism, Ch. IV.
} 
those that embroiled Samuel Clarke from 1712 to 1714. Clarke's Scripture Doctrine of the Trinity (1712) was seized upon by the High Church party in Convocation for its apparent support of Arianism, and, after a heated exchange of pamphlets, its author was censured by the Lower House in $1714 .{ }^{64}$ After that experience, which severely damaged his chances of advancement in the church, Clarke was especially keen to restore his own reputation for theological orthodoxy as well as that of Newtonianism in general. The power and popularity of High Church Tories were demonstrated during the Sacheverell trial and the ensuing elections. Low Church Whigs were put on their guard. In their apologetic writings references to kings as God's vice-regents and to the political role of God's providential will became increasingly frequent, as the gap separating Whig conceptual resources from those of Tories narrowed. Thus Court Whig political philosophy moved in a generally conservative direction from about 1710 to 1714 . Nevertheless, between 1689 and 1714 the nation was almost constantly at war with Papist absolutist forces and the succession was uncertain. As Kenyon notes, "it was only sensible for the Whigs to try to broaden the basis of their support, to represent themselves as a party of "the people." "However, with the Treaty of Utrecht in 1713, the accession of the thoroughly Whig George I in 1714, and the discrediting of the Tories by the 1715 Jacobite rebellion, the pressure on the Whigs relaxed "and the establishmentarian, elitist tendencies in whiggery... gained complete ascendancy." ${ }_{65}$ After 1714 Whig toadying to the court was very likely to be rewarded. Establishment Whigs developed, in Dickinson's words, "a conservative political ideology which laid as much or even more emphasis on authority and obedience as it did on liberty and the rights of subjects. . . . Now that they were firmly established in power the establishment Whigs required a political ideology which would persuade subjects to accept as legitimate their own exercise of authority. In other words, the Court Whigs no longer required an ideology designed to oppose those in power, but an ideology which would defend and justify the status quo." 66 The Vicar of Bray, it would seem, caricatured Whigs as much as Tories. ${ }^{67}$

\section{NEWTONIANISM AND THE COURT WHIG IDEOLOGY OF ORDER}

Where did the Newtonians, and where did their disloyal opposition, fit into the array of political allegiances in late seventeenth- and early eighteenth-century England? Leibniz himself had certain ideas on this subject. In 1713 he wrote to Johann Bernoulli in reference to his treatment in the Commercium epistolicum:

I understand that in England there are learned men who do not approve this procedure which is an affront to all grave and good men. And your guess just about hits the nail on the head, that is, that those who have little love for the House of Hanover have also

\footnotetext{
${ }^{64}$ Samuel Clarke, The Scripture Doctrine of the Trinity, in Works, Vol. IV, pp. 1-222; the rest of this volume contains Clarke's replies to his High Church critics and an account of proceedings in Convocation. Clarke undertook not to write any more about the Trinity and to submit himself to censure.

${ }^{65}$ Kenyon, Revolution Principles, p. 203.

${ }^{66}$ Dickinson, Liberty and Property, p. 126. On the partial convergence of Whig and Tory ideology during this period, see also Stromberg, Religious Liberalism, Ch. IX.

67 "When glorious Anne became our Queen,/ The Church of England's glory,/ Another face of things was seen,/ And I became a Tory . ..."
} 
meant to wound me; for an English friend writes to me that it seems to some that certain persons have acted not as mathematicians and Fellows of the Royal Society against a Fellow, but as Tories against a Whig.

A week later Leibniz rehearsed his theory to a Scottish acquaintance, injecting a note of puzzlement regarding Newton's own affiliations and behavior:

What you tell me, sir, is so comical it seems that my advisaries in the Royal Society have lately written against me as if I were a Whig rather than a member of their Society. I had believed that M. Newton was somewhat allied with the Whigs; thus I would not have imagined that the spirit of faction would go so far as to spread even into the mathematical sciences. ${ }^{68}$

Leibniz was correct to pull back from the charge that Newton and his friends were Tories. As Hall and Tilling remark, "If Leibniz was attributing Jacobitism to Newton and his friends, he could hardly have been further from the mark. Newton had been an opponent of James II, and his whole political life had been in the Whig interest." 69 That Leibniz could have mistaken the behavior of Newton and his associates for that of Tories is understandable, both in the context of the calculus disputes and in the later conflicts of 1715-1716. For the Newtonians were largely Court Whigs, and, as we have seen, Court Whigs and Tories came to share certain philosophical resources in the early eighteenth century.

It has already been noted that both Newton and Clarke were placemen, owing their position and advancement to the patronage of the crown and its ministers. Apologetic propagators of Newtonian natural philosophy and natural religion in the Boyle lectures shared Newton's Whiggism, and, like Newton himself, most of them came from the classic constituencies of the Court element in English politics: either as recipients of crown favor or as adherents of the latitudinarian Low Church faction: Bentley was a royal chaplain (to William), as were Clarke (to Princess Caroline and Queen Anne), Ibbot (Clarke's assistant at St. James's, Westminster, and chaplain to George I), and Derham (chaplain to the Prince of Wales, later George II). Bentley's great patron was the latitudinarian Bishop Stillingfleet, and John Harris's was the Whig Lord Chancellor William Cowper. Bentley was Keeper of the Royal Libraries and later Master of Trinity, where he served the Whig and Low Church interest (and, more spectacularly, his own). Among other Newtonian apologists, John Keill held crown office under Anne as Treasurer of the Palatines and, from about 1711, as "decypherer" to the Queen.

Part of the behavior of Newtonian divines can be understood by pointing to their interests as clerics; part, however, has to be referred to the circumstances of the latitudinarian Low Church faction to which they belonged. The cry "the Church in danger" was raised by Tory High Churchmen, but it was expedient at times, especially under Anne, for Low Churchmen to display their vigor in pursuing the sources of that "danger." Moreover, no Anglican cleric, however Low, needed much prompting from "High-flyers" to defend the church from the freethinking deists: Blount, Collins, Tindal, and Toland. It has to be understood that the freethinkers' assault was directed both at a certain conception of the nature of

\footnotetext{
${ }^{68}$ Leibniz to Bernoulli, 8 Aug. 1713, in Correspondence of Newton, Vol. VI, pp. 21-22; Leibniz to Thomas Burnet, 23 Aug. 1713, in Manuel, Portrait of Isaac Newton, p. 332, and Hall, Philosophers at War, p. 166. On Burnet as a source of Leibniz's political perceptions of England see Nicholas Jolley, "Leibniz on Locke and Socinianism," J. Hist. Ideas, 1978, 39:233-250.

${ }^{69}$ Correspondence of Newton, Vol. VI, p. $23 \mathrm{n}$.; also Vol. V, pp. xxii-xxiv.
} 
religion and the role of the church, on the one hand, and at a specific notion of the crown and its authority, on the other. This was a natural tendency insofar as the political order was still justified in religious terms. Before the Revolution the church had been far more united in its support of the crown than it was afterwards. The High Church faction contained many who denied divine legitimacy to William and Anne, while advocating divine right monarchy as a general principle. In many respects the High Church lower clergy were at war with the monarchy, while the Low Church bishops upheld its rights and powers and looked to it for support. It is useful, therefore, to treat the great conflicts of about 1691-1720 between latitudinarian Anglican Newtonians and freethinkers as disputes between elements of Whiggism: between radical Country Whigs (or "Commonwealthmen") and latitudinarian Court Whigs.

In his Christianity Not Mysterious of $1696 \mathrm{John}$ Toland attacked the role of revelation in Christian religion. In later amplifications of 1701 and 1702 Toland joined his views of the proper nature of Christianity to a wide-ranging attack on the Court element. While owning himself to be a member of the Established Church, Toland did not approve of its monopolistic powers:

... I do not think it a Doctrin of this Church to persecute or disturb those of another Religion which dos not teach or practice any Thing that's cruel, immoral, or profane. ... [W] [Were there is no Liberty of Conscience there can be no civil liberty, ... no possibility of Men's freely informing themselves concerning the true Religion, nor any Refuge or Protection for the Distrest, which is the greatest Glory of free Governments. ${ }^{70}$

Toland opposed arbitrary power both in religion and in politics: ". . . I am a great Common-wealthsman, the truth whereof I freely own . . ."; "I have always bin, now am, and ever shall be persuaded that all Sorts of Magistrats are made for and by the People, and not the People for or by the Magistrats. . . "71 He vehemently attacked absolute monarchy and the arbitrary power of king and court, especially when subject to "the Influence of Favorits; the Mischiefs of evil Counsillors; the Vanity, Lewdness, Flattery, Violence, Fraud, Venality, Bribery, and Rapine of the servil and mercenary Courtiers. ..." Arbitrary power is all the worse when the king "has religion prepar'd to justify, and Force to maintain him in whatsoever he dos, all his Subjects entirely depending on his pleasure. . .." While Toland sanctioned the legitimacy of William and Mary, he did so on classic Old Whig principles: "no King can ever be so good as one of [the people's] own making; as there is no Title equal to their Approbation, which is the only divine Right of all Magistracy, for the Voice of the People is the Voice of God." 72

As we have already seen, the conflict between freethinking deists and Anglican Newtonian apologists involved natural-philosophical and metaphysical issues similar to those which figured centrally in the Leibniz-Clarke disputes. We can

\footnotetext{
${ }^{70}$ John Toland, Anglia Libera: or the Limitation and Succession of the Crown of England Explained and Asserted ... (London, 1701), pp. 99-100; this book was written "to acquaint the House of Hanover with the true Nature of their Title": ibid., Sig. A6r.

${ }^{71}$ John Toland, Vindicius Liberius: or, M. Toland's Defence of Himself against the Late Lower House of Convocation . . . and a Justification of the Whigs and Commonwealthmen against the Misrepresentations of all their Opposers (London, 1702), pp. 125-126.

${ }^{72}$ Toland, Anglia Libera, pp. 9, 11, 26 (italics in original); in 1709 an aggressively Real Whig pamphlet was entitled Vox Populi Vox Dei, eliciting the High Church riposte The Voice of the People No Voice of God, see Kenyon, Revolution Principles, pp. 123-125.
} 
now see that such cultural controversies were embedded within a structure of conflict over the proper order of society. The views of freethinking Commonwealthmen posed a threat to the material interests of Court Whig divines. A response was therefore demanded, and that response fit the scope of the interests at stake: it was immediate and massive. In composing their replies to the radical freethinkers, the Newtonians were rehearsing the major themes of Clarke's replies to Leibniz.

\section{PHILOSOPHICAL RESOURCES OF POLITICAL COMMENT AMONG ANGLICAN NEWTONIANS}

In the period preceding the 1715-1716 disputes with Leibniz latitudinarian Court Whigs like Samuel Clarke were faced with a set of interrelated political problems. How to buttress the sort of moral and social order which acknowledged the spiritual superintendence of the clergy in general? How to put maximum practical political distance between themselves and the deistical and heretical tendencies with which their High Church opponents were attempting to associate them? How best to celebrate the powers of the king and court upon which their security and preferment depended? In coping with each of these problems they invoked the natural-philosophical and metaphysical resources which came to form the core of the Leibniz-Clarke exchanges. Most significantly, the Newtonian apologists invoked the notion of God's supreme will and the attendant liberty of moral agents.

In his Boyle lectures Clarke linked the action of God's free will in nature to mankind's free moral choice:

. . God, by Creating things, manifests it to be his Will, that things should be what they Are. And as Providence wonderfully preserves things in their present State; all necessary Agents, by constantly and regularly obeying the Laws of their Nature, necessarily employ all their Natural Powers in promoting the same end; so 'tis evident it cannot but be the Will of God, that all rational Creatures, whom he has indued with those singular Powers and Faculties, of Understanding, Liberty and Free-Choice, whereby they are exalted in Dignity above the rest of the World; should likewise imploy those their extraordinary Faculties in preserving the Order and Harmony of the Creation, and not in introducing Disorder and Confusion therein. ${ }^{73}$

If God does not have free will, then man surely cannot either. And if either God or man is a necessary being, then it would be meaningless to speak of moral accountability. To threaten the notion of the moral accountability of individual men for their individual actions would be to erode the moral basis of proper social order.

At the root of this threat was the contention that matter might think or contain principles of self-action within itself. Only if matter were inanimate, brute, and stupid would God's will be necessary to set it into motion, sustain it in motion, and produce the phenomena of sentience. Only if matter and spirit were conceived separate and distinct could the immortality of the soul be asserted and the afterlife be used as a sanction on man's mundane moral conduct. And only if matter were inanimate could free will be unambiguously attributed to God and man. Hence, no Newtonian apologist omitted to attack freethinkers' matter theory and to identify its pernicious moral consequences. If matter and motion

${ }^{73}$ Clarke, Obligations of Natural Religion, pp. 639-640. 
sufficed to explain sentience, then, as Clarke wrote, "every Thought in a Man's Mind must likewise be necessary, and depending wholly upon external Causes; And there could be no such thing in Us, as Liberty, or a Power of Selfdetermination. Now what Ends and Purposes of Religion, mere Clocks and Watches are capable of serving needs no long and nice consideration." ${ }^{74}$ A hylozoist matter theory would erode the whole system of obligations and sanctions that kept a hierarchical social order in place. If views of an afterlife were discarded, then what difference did morality make in this life? And if morality lost its bite, then what faith could be accorded contracts, promises, and commitments? Thus Harris recognized that the deists' corporeal and necessary God "makes Him nothing at all but Nature, and deprives both Him and us of the Noble Principle of Freedom of Will: and then they know that there can be no such things as Rewards and Punishments, . . . and consequently that they may do any thing that they have a mind to." 75 Ibbot linked the idea that "Matter is endu'd with a Power of Thought, and a Principle of Self-motion" to the mortality of the soul; if the soul were mortal, then "there is no account to be given of our present Carriage and Behaviour, nor any future State of Rewards or Punishments." Anyone who believed that, whatever he called himself, was a practical atheist and could not faithfully enter into "Bargains and Contracts, Oaths and Promises." 76 Bentley saw the system of deference in society at risk from hylozoism; the "Sect of Free-thinkers" he styled "a Commonwealth of Savages, where nobody governs nor nobody obeys." Necessitarianism justified self-interested arrogance; as Bentley told George I in a sermon, "no one . . . that lives in society . . . can be said to live to himself. No, he lives to his prince and his country." Ibbot feared that the thrust of deism was to "exempt Men . . . from a due Submission and Obedience to their lawful Superiors and Governours, whether in Church or State." And John Hancock saw hylozoist necessitarianism as a double-edged sword: as such "Principles encourage Princes to oppress their Subjects, so they set subjects at liberty to disturb their Governours." 77

A spiritually governed moral order was thus seen to depend upon human and divine liberty; these in turn depended upon insensible and inanimate matter. The doctrine of fate and necessity contravened these requirements and was seen as the strategy of groups who wished to dissolve proper patterns of deference and obligation. ${ }^{78}$ God's supreme will had to have a role in a justly constituted natural philosophy. How, then, to reconcile God's volitional providence with the concept of second causes? If this reconciliation could not be effected, then a theistic religion would be seen to be at odds with natural philosophy: a state of affairs rejected by all Anglican Newtonians. Of "all the variable Events," Clarke preached,

\footnotetext{
${ }^{74}$ Samuel Clarke, A Third and Fourth Defense of [His Letter] to Mr. Dodwel (2nd ed., London, 1712), p. 59; quoted in John H. Gay, "Matter and Freedom in the Thought of Samuel Clarke," $J$. Hist. Ideas, 1963, 24:85-105, the best source for Clarke's views on human liberty.

${ }^{75}$ Harris, Atheistical Objections, Sermons IV-V, p. 49; see also Clarke, Remarks upon a Book, pp. 41-42, 44-45; Gay, "Matter and Freedom," pp. 88-90.

${ }^{76}$ Ibbot, Course of Sermons, Pt. II, pp. 9, 75; also on this point see Redwood, Reason, Ridicule and Religion, pp. 106-114. For the background of freethinkers' hylozoism in 17th-century mortalism: Christopher Hill, Milton and the English Revolution (Harmondsworth: Penguin, 1979), Ch. XXV.

${ }^{77}$ Bentley, Remarks upon a Late Discourse, p. 300; Richard Bentley, "A Sermon Preached Before King George I. On February the third, 1716-7," in Works, Vol. III, pp. 263-277, on p. 268; Ibbot, Course of Sermons, Pt. II, p. 11; Hancock, Arguments to Prove the Being of God, p. 254.

${ }^{78}$ For a contemporary exposure of the freethinkers' interests, see Harris, Atheistical Objections, Sermons IV-V, p. 50.
} 
that happen in the Universe, there is and can be in Nature no other proper and efficient Cause; but only the Free Will of rational and intelligent Creatures . . . and the Supreme Power of God, directing by his omnipresent Providence, (according to certain Wise Laws or Rules, established by, and entirely depending upon his own good pleasure,) the inanimate Motions of the whole material and unintelligent World.

It was only the enemy of true religion who used the findings of natural philosophy as arguments against Christian theism:

Ridiculous therefore is the Arguing of the Infidel and Irreligious; who presently thinks himself secure of excluding the Providence of God, if he can show a Thing to be brought about by Natural Causes. . . . For what are Natural Causes? Nothing but those Laws and Powers, which God of his own good pleasure has implanted in the several parts of Matter, in order to make them Instruments of fulfilling his supreme Will. ${ }^{79}$

These laws God appoints and continuously sustains: God's will in nature acts constantly and is not constrained by laws. ${ }^{80}$ It is evident therefore that Newtonian Anglicans had been engaged for some time in efforts to secure the moral order of society (and the moral authority of the clergy) from threats posed by freethinking deists whose strategy it was to deny both divine and human free will.

Newtonian Anglicans also deployed philosophical resources to comment upon the proper scope of monarchical will. Of particular interest in this connection is the variation between the celebration of unrestricted will found in the LeibnizClarke exchanges and earlier statements found in Clarke's sermons preached before the queen. It was by no means the natural position of any element in the Whig party, even of Court Whigs, to assert the absolute supremacy of the royal will. Speaking in overtly political contexts, Court Whig apologists like Clarke more commonly conjoined a proper exercise of will to the dictates of reason or law, or they even erected unaccustomed distinctions between the characteristics of God and those of kings. God could act howsoever he wished, but it would be a contradiction of his benevolent nature to act against the principle of what is good and what is reasonable. To say this, however, was not to restrict the absolute power of God's will, or so Clarke insisted. The requirements of one apologetic context sometimes seemed to conflict with those of another, and there are passages in Clarke's sermons where the tension may be discerned. No restrictions could be accepted upon the divine will, yet any Whig had to place some limitations upon the exercise of will by God's vice-regents. Thus Clarke labored to reconcile cosmic Toryism with mundane Whiggism:

These are lively descriptions of arbitrary Power indeed; arbitrary, not in the Sense that the Tyrants of This World have occasioned that word to be used, when it signifies a Power of doing unreasonable and unjust things, a Power of Violence and unrighteous oppression, a Power of acting according to mere Will and Pleasure without Right or Reason; but in God, arbitrary or irresistible Power, tho' it is indeed a Power of doing all things absolutely without controul, yet it is so a Power of doing them, as that at the

\footnotetext{
${ }^{79}$ Clarke, "The Event of Things not always Answerable to Second Causes," in Sermons, Vol. VI, pp. 187-201, on pp. 193-194, 196.

${ }^{80}$ See, e.g., Maxwell, "A Summary of the Controversy," p. 61; see similar views of God's sustenance in Clarke, Obligations of Natural Religion, p. 600; Clarke, "Of the Omnipresence of God," in Works, Vol. I, pp. 46-52, on p. 48; Cheyne, Philosophical Principles of Natural Religion, pp. 5-6.
} 
same time there is always with the notion of That Power, necessarily and inseparably connected, an Idea of infinite Reason, Wisdom, and Goodness. . . . For in God, Will and Reason are one and the same thing . . . ; whereas in the Rulers of this World, they too often signify things contrary to each other: Governing according to Law or Reason, and governing according to absolute Will or Pleasure, being on Earth the two most opposite forms of Government. ${ }^{81}$

Arbitrary power in men is to be "detested, dreaded, and abhorred," whereas in God it is the "great Principle and Foundation of all Religion." In a sermon preached before the queen in 1705 Clarke managed both to characterize princes as God's delegates and to remind her of classic Whig principles:

And here is the true and immortal Glory of wise and good Princes, that as they represent God in the Exercise of Power and Authority in the World, so they resemble him also in the Application of that Power to serve the Ends of Virtue and Goodness in promoting the publick Happiness of Mankind. . . . Those whom [God] has endued with Power and Authority to represent him on Earth, are then most truly and illustriously his Vice-gerents, when they look upon a large Extent of Power, to be only a Greater Compass of doing good; when they imitate God, in being Lovers and Preservers of Mankind, and making Government a Protection and Security to all that live under it. ${ }^{82}$

The concrete political circumstances over which Whiggery had triumphed were too recent and vivid for any Whig to trifle with absolutism. Under the rule of James II, according to Clarke, it pleased "God to threaten us with the Rod of arbitrary Power, and with the fears of Popish Slavery"; the Duke of Marlborough's victory over the French at Mons was counted as God's providential interposition, saving England from Rome and absolutist tyranny. ${ }^{83}$ There was no sense in which Court Whig or Low Church interests could be served by celebrating the sort of sovereign will manifested in the reign of the last Stuart or of the Sun King. Likewise there was no sense in which latitudinarian Court Whig interests could be served by subsuming their philosophy of will to that of radical Country Whigs like John Toland. Differences in Court Whig apologists' accounts of sovereign will can be referred to the different, and historically changing, contexts in which the accounts appeared. Clarke's efforts to ingratiate his Low Church faction with the High Church-leaning queen manifest themselves, for example, in a deferential sermon of 1705. Clarke assured Anne that proper religion taught subjects what were their duties towards those whom God's will has set over them: "willing and cheerful Obedience to [their commands]: In delighting to promote their Honour, and to increase amongst Men that Duty and Respect, which is due to Authority: In thinking them that rule well, worthy of double Honour . . . [and in] a careful and diligent and conscientious Discharge of our several Duties, each in our respective Stations. . . ." 84

\footnotetext{
${ }^{81}$ Samuel Clarke, "Of the Omnipotence of God," in Works, Vol. I, pp. 53-65, on pp. 54-55; compare Clarke, "Of the Liberty of Moral Agents," in Sermons, Vol. IV, pp. 1-17, esp. p. 12. The dating and setting of the quoted sermon is not known, but there are indications that it is from about the time of the 1704-1705 Boyle lectures and may have been preached before the queen.

${ }^{82}$ Samuel Clarke, "Sermon Preach'd before the Queen . . . on Sunday, December the 30th, 1705," in Sermons, Vol. XI, pp. 1-21, on pp. 17-18; compare Clarke, "Sermon Preach'd before the Queen . . .8th of March, 1709-10," in ibid., pp. 65-83.

${ }^{83}$ Samuel Clarke, "Sermon Preach'd before the Honourable House of Commons . . . November 22, 1709," in ibid., pp. 41-63, on p. 42.

${ }^{84}$ Clarke, "Sermon Preach'd before the Queen . . . December the 30th, 1705," p. 16.
} 


\section{SUMMARY AND CONCLUSION}

Historians of ideas like their subjects to be consistent. Inconsistency is viewed as a mark upon a thinker's intellectual stature, and historians often labor to show that the apparent inconsistency of highly regarded figures is really a manifestation of some deep-seated psychological or methodological consistency. An alternative approach is to assess utterances in their contexts of use, recognizing that ideas may be multifunctional and that the pertinent historical circumstances affecting their uses may be complex and changing. Variations in Court Whig accounts of sovereign will are best taken as signs of the highly political nature of such conceptions and of the complexly shifting settings in which they were produced. In reminding the monarch of classic Whig political principles apologists like Clarke stressed lawful limitations upon royal will and produced appropriate accounts of divine will and wisdom. Elsewhere, Court Whigs were concerned to defend their interests and notions of order from radical Country Whig assaults, and here they were far more inclined to remove practical limits upon sovereign will. This is one of our best clues to the political connections between the Newtonians' fight against freethinking deists and the campaign of 1715-1716 against Leibniz. Cosmological similarities between Leibniz's philosophy and that of the English freethinkers may be discerned in the relevant texts, but the best indication that such similarities were historically significant lies in the fact that they elicited similar responses from Newtonian apologists. English deism, to be sure, was regarded as a serious threat, but that danger was made more formidable by the possibility that the Hanoverian succession would bring Leibniz to England where his philosophy might gain court countenance and provide useful resources to the Commonwealthmen.

It bears repeating that the perceived political uses of Leibniz's philosophy of God and nature in England have no necessary relationship to Leibniz's intentions or to the interests which might have sustained his views on the Continent. Leibniz was not a player in the English political game, although part of the significance of his philosophy in England arose from the sense that he might become a leading player at any moment. There is no evidence that Leibniz's philosophy, however many similarities were perceived between it and the ideas of Collins, Toland, and their like, was developed with a view to sustaining Country Whig conceptions of political order. There is thus no necessity to inquire here into possible political uses of Leibnizian thought across the Channel. ${ }^{85}$

Since the argument of this paper has been rather complex, it is best to conclude by reviewing its basic structure and drawing out several of its implications. We started by identifying a well-known intellectual controversy between two individual philosophers. We then showed that the philosophical resources each of them employed had a history of uses by antagonistic social groups in England. Natural-philosophical and metaphysical conceptions were routinely employed to comment upon political order, and those conceptions involved in the Leibniz-

\footnotetext{
${ }^{85}$ Intriguing materials for such a project are to be found in Leroy E. Loemker, Struggle for Synthesis: The Seventeenth Century Background of Leibniz's Synthesis of Order and Freedom (Cambridge, Mass.: Harvard Univ. Press, 1972), Jon Elster, Leibniz et la formation de l'esprit capitaliste (Paris: Aubier Montaigne, 1975), and esp. R. W. Meyer, Leibnitz and the Seventeenth-Century Revolution, trans. J. P. Stern (Cambridge: Bowes \& Bowes, 1952). Meyer explores the relations between Leibniz's monadological theory of matter and his search for a harmony of European interests suitable to withstand the absolutist will of Louis XIV.
} 
Clarke exchanges were of major significance in the political and apologetic writings of that period. Having shown that conflicting conceptions of political and moral order were sustained by the invocation of diverging notions of divine and natural order, we could see how important social interests were at stake in the intellectual disputes in question. The evaluations of Leibniz's philosophy by the Newtonians followed the patterns established in the history of apologetic uses of similar resources by English freethinkers; that congruence supports the conclusion that such uses were an important basis for judgments of naturalphilosophical claims in the period. Considerations of social use did not follow autonomous processes of evaluation but were in fact central to natural philosophers' judgments.

This paper therefore is based upon a post-Koyréan historiographic sensibility. It has shown that late seventeenth- and early eighteenth-century conceptions of God's attributes and his role in nature functioned in overtly political as well as natural-philosophical and theological settings. Since these settings overlapped significantly, this paper set out to take the overlaps seriously and to see how they were constructed through processes of use in context and what consequences such uses had for the career of natural philosophy. For some time now explorations of the overlaps between natural philosophy and religion have been routine and uncontentious: a state of affairs we owe to the boundary-breaking work of Koyré and his followers. To recognize the significance of political uses of natural philosophy and natural religion is to extend and develop Koyré's historical sensibilities in the direction they now seem best suited to go. 
http://www.jstor.org

\title{
LINKED CITATIONS
}

- Page 1 of 3 -

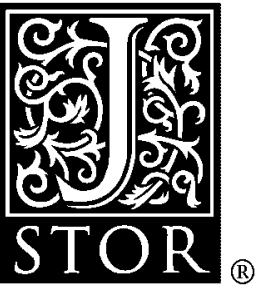

You have printed the following article:

Of Gods and Kings: Natural Philosophy and Politics in the Leibniz-Clarke Disputes

Steven Shapin

Isis, Vol. 72, No. 2. (Jun., 1981), pp. 187-215.

Stable URL:

http://links.jstor.org/sici?sici=0021-1753\%28198106\%2972\%3A2\%3C187\%3AOGAKNP\%3E2.0.CO\%3B2-C

This article references the following linked citations. If you are trying to access articles from an off-campus location, you may be required to first logon via your library web site to access JSTOR. Please visit your library's website or contact a librarian to learn about options for remote access to JSTOR.

\section{[Footnotes]}

\author{
${ }^{1}$ Leibniz and the Vis Viva Controversy \\ Carolyn Iltis \\ Isis, Vol. 62, No. 1. (Spring, 1971), pp. 21-35. \\ Stable URL: \\ http://links.jstor.org/sici?sici=0021-1753\%28197121\%2962\%3A1\%3C21\%3ALATVVC\%3E2.0.CO\%3B2-E
}

${ }^{1}$ Eighteenth-Century Attempts to Resolve the Vis viva Controversy

Thomas L. Hankins

Isis, Vol. 56, No. 3. (Autumn, 1965), pp. 281-297.

Stable URL:

http://links.jstor.org/sici?sici=0021-1753\%28196523\%2956\%3A3\%3C281\%3AEATRTV\%3E2.0.CO\%3B2-G

\footnotetext{
${ }^{2}$ Physics and Metaphysics in Newton, Leibniz, and Clarke

Margula R. Perl

Journal of the History of Ideas, Vol. 30, No. 4. (Oct. - Dec., 1969), pp. 507-526.

Stable URL:

http://links.jstor.org/sici?sici=0022-5037\%28196910\%2F12\%2930\%3A4\%3C507\%3APAMINL\%3E2.0.CO\%3B2-0

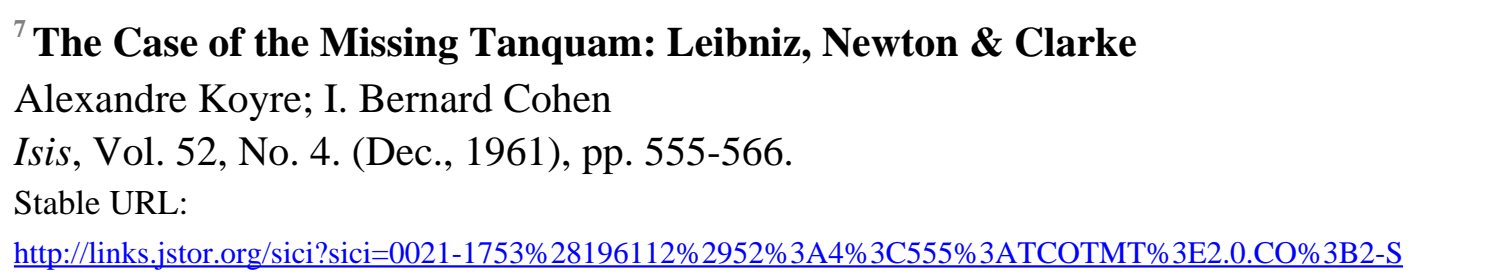

NOTE: The reference numbering from the original has been maintained in this citation list. 
http://www.jstor.org

\section{LINKED CITATIONS}

- Page 2 of 3 -

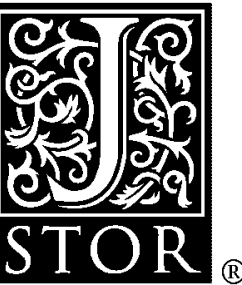

\section{${ }^{7}$ Review: [Untitled]}

Reviewed Work(s):

The Correspondence of Isaac Newton. Volume II. 1676-1687 by H. W. Turnbull

A. Rupert Hall

Isis, Vol. 52, No. 1. (Mar., 1961), pp. 115-117.

Stable URL:

http://links.jstor.org/sici?sici=0021-1753\%28196103\%2952\%3A1\%3C115\%3ATCOINV\%3E2.0.CO\%3B2-Y

${ }^{18}$ Christian Theology and the Newtonian Science: The Rise of the Concept of the Laws of Nature

Francis Oakley

Church History, Vol. 30, No. 4. (Dec., 1961), pp. 433-457.

Stable URL:

http://links.jstor.org/sici?sici=0009-6407\%28196112\%2930\%3A4\%3C433\%3ACTATNS\%3E2.0.CO\%3B2-4

\section{${ }^{19}$ Newton, Creation, and Perception}

Martin Tamny

Isis, Vol. 70, No. 1. (Mar., 1979), pp. 48-58.

Stable URL:

http://links.jstor.org/sici?sici=0021-1753\%28197903\%2970\%3A1\%3C48\%3ANCAP\%3E2.0.CO\%3B2-O

${ }^{29}$ The Case of the Missing Tanquam: Leibniz, Newton \& Clarke

Alexandre Koyre; I. Bernard Cohen

Isis, Vol. 52, No. 4. (Dec., 1961), pp. 555-566.

Stable URL:

http://links.jstor.org/sici?sici=0021-1753\%28196112\%2952\%3A4\%3C555\%3ATCOTMT\%3E2.0.CO\%3B2-S

\footnotetext{
${ }^{35}$ The Anglican Origins of Modern Science: The Metaphysical Foundations of the Whig Constitution

James R. Jacob; Margaret C. Jacob

Isis, Vol. 71, No. 2. (Jun., 1980), pp. 251-267.

Stable URL:

http://links.jstor.org/sici?sici=0021-1753\%28198006\%2971\%3A2\%3C251\%3ATAOOMS\%3E2.0.CO\%3B2-9
}

NOTE: The reference numbering from the original has been maintained in this citation list. 
http://www.jstor.org

\section{LINKED CITATIONS \\ - Page 3 of 3 -}

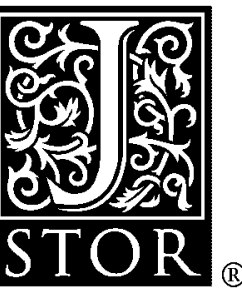

\section{${ }^{48}$ Toland and Leibniz \\ F. H. Heinemann}

The Philosophical Review, Vol. 54, No. 5. (Sep., 1945), pp. 437-457.

Stable URL:

http://links.jstor.org/sici?sici=0031-8108\%28194509\%2954\%3A5\%3C437\%3ATAL\%3E2.0.CO\%3B2-A

\section{${ }^{48}$ Toland and Leibniz}

F. H. Heinemann

The Philosophical Review, Vol. 54, No. 5. (Sep., 1945), pp. 437-457.

Stable URL:

http://links.jstor.org/sici?sici=0031-8108\%28194509\%2954\%3A5\%3C437\%3ATAL\%3E2.0.CO\%3B2-A 